\title{
28 Research Soure \\ Identification of the Wheat VQ Protein Family and Expression Analysis of Candidate Genes Associated with Seed Dormancy and Germination
}

\section{Xinran Cheng}

Anhui Agriculture University

\section{Chang Gao}

Anhui Agriculture University

Xue Liu

Anhui Agriculture University

Dongmei $\mathrm{Xu}$

Anhui Agriculture University

\section{Xu Pan}

Anhui Agriculture University

Wei Gao

Anhui Agriculture University

\section{Shengnan Yan}

Anhui Agriculture University

Hui Yao

Anhui Agriculture University

Jiajia Cao

Anhui Agriculture University

\section{Xiaoyu Min}

Anhui Agriculture University

Jie Lu

Anhui Agriculture University

Cheng Chang

Anhui Agriculture University

Haiping Zhang ( $\sim$ Zhanghaip@ahau.edu.cn )

Anhui Agriculture University

\section{Chuanxi Ma}

Anhui Agriculture University

\section{Research article}

Keywords: Wheat, VQ Protein Family, Evolution Analysis

Posted Date: December 2nd, 2020 
DOI: https://doi.org/10.21203/rs.3.rs-117872/v1

License: (c) (i) This work is licensed under a Creative Commons Attribution 4.0 International License. Read Full License 


\section{Abstract}

Background: Seed dormancy and germination determine wheat pre-harvest sprouting resistance and thereby affect grain yield and quality. Arabidopsis $V Q$ genes have been shown to influence seed germination; however, the functions of wheat $V Q$ genes have not been characterized.

Results: In this study, we identified 65 TaVQ genes in common wheat and named them TaVQ1-65. We identified 48 paralogous pairs, 37 of which had Ka/Ks values lager than 1, suggesting that most TaVQ genes have suffer positive selection. Chromosome location, gene structure, promoter element and gene ontology annotation showed that the structure of the genes determined their function and that structural change reflected functional diversity. The transcriptome expression analysis of 62 TaVQ genes and microarray analysis of $11 \mathrm{TaVQ}$ genes indicated that they played important roles in diverse biological processes. We compared TaVQ gene expression and corresponding seed germination index values among wheat varieties with contrasting seed dormancy and germination phenotypes and found that 21 TaVQ genes may be related to seed dormancy and germination.

Conclusions: Sixty-five TaVQ proteins were identified for the first time in common wheat, and bioinformatics analysis was performed to investigate their phylogenetic relationships and evolutionary divergence. The qRT-PCR data showed that $21 \mathrm{TaVQ}$ candidate genes were potentially involved in seed dormancy and germination. These findings provide effective information for further cloning and functional analysis of TaVQ genes, as well as useful candidate genes for improvement of PHS resistance in wheat.

\section{Background}

Wheat is a widely cultivated gramineous plant and one of the three most important cereals in the world [1]. It is well known that wheat is a heterologous hexaploid derived from three closely related ancestors that have undergone two rounds of natural hybridization. Therefore, the large and complex genome of wheat (17 Gb) poses a significant challenge for wheat genome research [2,3]. The completion of a whole genome sequence for wheat based on single chromosome sequencing has laid the foundation for wheat genomics research and wheat gene family identification.

VQ proteins are a class of plant-specific proteins with five highly conserved amino acids in the core FxxxVQxLTG sequence of the VQ motif [4], in which $x$ represents any amino acid and VQ is a highly conserved pair of amino acid residues. Research on the VQ proteins has shown that the last three amino acids in almost all species are LTG, although some species have other variants, including FTG, ITG, LTA, and VTG [5]. In some VQ proteins of Gramineae species such as rice, maize, and Moso bamboo, VQ has been mutated to VH in the conserved domain $[5,6]$. VQ proteins are generally less than 300 aa in length and contain no or few introns [7]. To date, 34, 40, 61, 18, and 74 VQ proteins have been identified in Arabidopsis, rice, maize, grape, and soybean, respectively [6, 9-11]. According to bioinformatics prediction and experimental verification, some Arabidopsis VQ proteins are located in the nucleus, some in the plastid, and a few partly in the mitochondria [12].

VQ proteins play important roles in the regulation of plant growth and development and the response to abiotic and biotic stress [5-7, 13-17]. For instance, AtCaMBP25 (AtVQ15) negatively regulates osmotic stress response during the early stages of seed germination and growth in Arabidopsis [13]. Likewise, AtVQ9 expression responds strongly to $\mathrm{NaCl}$ treatment, and its mutation enhances salt stress tolerance in Arabidopsis [16]. VQ54 and VQ19 in maize, as well as $V Q 2, V Q 16$, and $V Q 20$ in rice, are highly expressed under drought induction $[6,11]$. Soybean $V Q 6$ 
and $V Q 53$ are highly expressed in roots and stems under low nitrogen conditions [10]. SIB1 (Sigma factor binding protein 1, also known as AtVQ23) was the first VQ motif protein discovered in Arabidopsis and participates in plant disease resistance signaling pathways [15]. AtVQ21 (MSK1) transgenic plants show enhanced resistance to the pathogen Pseudomonas syringae but reduced resistance to Botrytis cinerea $[13,18]$. AtVQ22 negatively regulates JA-mediated disease resistance signaling pathways [19], and rice VQ22 shows high expression levels after rice blast infection [5]. AtVQ14 (IKU1) participates in the regulation of endosperm development, thereby affecting the size of Arabidopsis seeds [20]. AtVQ29 is involved in the photomorphogenesis of Arabidopsis seedlings and flowering time regulation [9]. In addition, the growth of $V Q 17, V Q 18, V Q 8$, and VQ22 transgenic Arabidopsis plants is inhibited, indicating that these genes play crucial roles in plant growth and development [8].

VQ proteins came to the attention of researchers because of their interactions with WRKY transcription factors, which are involved in regulating the plant's defense response system $[13,15]$. WRKY transcription factors belong to a large gene family and are ubiquitous in plants. Studies have shown that WRKY transcription factors are widely involved in plant growth and development and in resistance to adverse conditions [21-38]. For example, AtVQ14 and AtWRKY10 interact to form a protein complex that affects seed size in Arabidopsis [20]. AtVQ15and AtWRKY25 interact and participate in high salt and osmotic stress response [13]. The interaction between AtVQ22 and AtWRKY28 negatively regulates JA-mediated disease resistance signaling pathways [19]. AtVQ23 (SIB1) and AtVQ16 (SIB2) interact with WRKY33 to enhance the binding capacity of WRKY33 to the W-box, thereby regulating plant disease resistance $[6,15]$. AtVQ21 can form ternary complexes with AtWRKY33 and AtMPK4 to regulate plant growth and disease resistance [4,39]. In brief, VQ proteins are transcriptional regulatory cofactors that participate in growth and developmental processes and stress resistance through their interactions with transcription factors. However, until now, the VQ gene family has not been characterized in common wheat.

Pre-harvest sprouting (PHS) refers to the germination of wheat seeds within the spike of the mother plant that occurs in rainy or high moisture conditions before harvest. A series of physiological and biochemical reactions take place in wheat grains when PHS occurs. The activity of hydrolases such as amylase and proteolytic enzymes is enhanced, leading to starch and protein degradation and seriously affecting wheat processing quality and utilization value. In the international wheat market, when the germination rate of commercial wheat reaches $5 \%$, it is regarded as feed wheat and its price is reduced, causing serious economic losses to producers [40-41]. Seed dormancy and germination traits determine wheat PHS resistance: wheat varieties with higher levels of dormancy or lower germination percentages show higher resistance to PHS. Therefore, the identification of candidate genes that control seed dormancy and germination may help to reduce yield and quality losses caused by PHS. Previously, in Arabidopsis, VQ18 and VQ26 were found to be involved in seed germination via the ABA signaling pathway [42]. However, the functions of VQ genes in common wheat are largely unknown.

The objectives of this study were to identify TaVQ genes and to perform bioinformatics analysis, including phylogenetic tree construction and characterization of gene structures, conserved domains, chromosome positions, expression patterns, and promoter elements. In addition, we measured the expression levels of TaVQ genes in wheat varieties with contrasting seed dormancy and germination phenotypes by qRT-PCR to identify TaVQ gene family members that were potentially involved in seed dormancy and germination.

\section{Results}

\section{Identification and attribute analysis of VQ candidate genes in wheat}


A total of 65 TaVQ genes were identified, mapped to wheat chromosomes, and named TaVQ1-TaVQ65. The length of the encoded proteins ranged from 127 to 723 aa, with an average length of 220 aa. Their MWs ranged from 13,377.16 Da (TaVQ52) to 61,926.76 Da (TaVQ1). Information on chromosome positions, ORF lengths, and exon numbers is provided in Table 1. The majority of genes included one exon, and only four genes (TaVQ13/-17/-18/-53) contained two exons. 
Table 1

Detailed information about the predicted TaVQ genes.

\begin{tabular}{|c|c|c|c|c|c|c|c|}
\hline Name & Gene ID & Location & $\begin{array}{l}\text { ORF } \\
\text { length(bp) }\end{array}$ & $\begin{array}{l}\text { Size } \\
\text { (aa) }\end{array}$ & MW(Da) & pl & Exons \\
\hline TaVQ1 & TraesCS1A02G338700 & $\begin{array}{l}\text { Chr1A:528102140- } \\
528103155\end{array}$ & 2172 & 723 & 61926.76 & 4.99 & 1 \\
\hline TaVQ2 & TraesCS2A01G487800 & $\begin{array}{l}\text { Chr2A:722518069- } \\
\text { 722518557 }\end{array}$ & 489 & 162 & 16310.14 & 8.11 & 1 \\
\hline TaVQ3 & TraesCS2A01G517000 & $\begin{array}{l}\text { Chr2A:740346569- } \\
\text { 740347388 }\end{array}$ & 636 & 211 & 22232.87 & 9.77 & 1 \\
\hline TaVQ4 & TraesCS2B01G314600 & $\begin{array}{l}\text { Chr2B:449669843- } \\
449671002\end{array}$ & 990 & 329 & 34759.36 & 9.97 & 1 \\
\hline TaVQ5 & TraesCS2B01G515400 & $\begin{array}{l}\text { Chr2B:710280174- } \\
710280671\end{array}$ & 498 & 165 & 16828.73 & 6.09 & 1 \\
\hline TaVQ6 & TraesCS2B01G545500 & $\begin{array}{l}\text { Chr2B:742454459- } \\
\text { 742455094 }\end{array}$ & 636 & 211 & 22348.05 & 9.87 & 1 \\
\hline TaVQ7 & TraesCS2D01G296200 & $\begin{array}{l}\text { Chr2D:378525321- } \\
378526310\end{array}$ & 990 & 329 & 34841.5 & 9.97 & 1 \\
\hline TaVQ8 & TraesCS2D01G488100 & $\begin{array}{l}\text { Chr2D:587696143- } \\
\text { 587696631 }\end{array}$ & 489 & 162 & 16649.49 & 6.92 & 1 \\
\hline TaVQ9 & TraesCS2D01G518600 & $\begin{array}{l}\text { Chr2D:608745741- } \\
608746370\end{array}$ & 630 & 209 & 22044.73 & 9.93 & 1 \\
\hline TaVQ10 & TraesCS3A01G044200 & $\begin{array}{l}\text { Chr3A:23866681- } \\
23867710\end{array}$ & 771 & 256 & 26516.25 & 6.49 & 1 \\
\hline TaVQ11 & TraesCS3A01G190200 & $\begin{array}{l}\text { Chr3A:235380871- } \\
235382316\end{array}$ & 702 & 233 & 24220.28 & 6.11 & 1 \\
\hline TaVQ12 & TraesCS3A01G334400 & $\begin{array}{l}\text { Chr3A:580608595- } \\
580609062\end{array}$ & 468 & 155 & 15944.31 & 5.77 & 1 \\
\hline TaVQ13 & TraesCS3B01G197900 & $\begin{array}{l}\text { Chr3B:225257528- } \\
225258102\end{array}$ & 486 & 161 & 17544.85 & 5.7 & 2 \\
\hline TaVQ14 & TraesCS3B01G219100 & $\begin{array}{l}\text { Chr3B:262901818- } \\
262902606\end{array}$ & 789 & 262 & 27481.07 & 9.16 & 1 \\
\hline TaVQ15 & TraesCS3B01G365300 & $\begin{array}{l}\text { Chr3B:577490273- } \\
577490731\end{array}$ & 459 & 152 & 15724.13 & 6.07 & 1 \\
\hline TaVQ16 & TraesCS3B01G478300 & $\begin{array}{l}\text { Chr3B:726621717- } \\
\text { 726622121 }\end{array}$ & 405 & 134 & 14557.72 & 10.15 & 1 \\
\hline TaVQ17 & TraesCS3D01G036600 & $\begin{array}{l}\text { Chr3D:13254563- } \\
\text { 13257748 }\end{array}$ & 774 & 257 & 26587.4 & 6.7 & 2 \\
\hline TaVQ18 & TraesCS3D01G174600 & $\begin{array}{l}\text { Chr3D:156240964- } \\
156246686\end{array}$ & 489 & 162 & 17816.12 & 5.45 & 2 \\
\hline TaVQ19 & TraesCS3D01G193700 & $\begin{array}{l}\text { Chr3D:184379368- } \\
184380834\end{array}$ & 717 & 238 & 24770.88 & 6.12 & 1 \\
\hline
\end{tabular}




\begin{tabular}{|c|c|c|c|c|c|c|c|}
\hline Name & Gene ID & Location & $\begin{array}{l}\text { ORF } \\
\text { length(bp) }\end{array}$ & $\begin{array}{l}\text { Size } \\
\text { (aa) }\end{array}$ & MW(Da) & pl & Exons \\
\hline TaVQ20 & TraesCS3D 02G272900 & $\begin{array}{l}\text { Chr3D:378529151- } \\
378530444\end{array}$ & 2154 & 717 & 61510.13 & 5 & 1 \\
\hline TaVQ21 & TraesCS4A01G369400 & $\begin{array}{l}\text { Chr4A:641502472- } \\
641502912\end{array}$ & 441 & 146 & 14995.88 & 11.33 & 1 \\
\hline TaVQ22 & TraesCS4A01G411100 & $\begin{array}{l}\text { Chr4A:683787345- } \\
683787800\end{array}$ & 456 & 151 & 15683.79 & 10.54 & 1 \\
\hline TaVQ23 & TraesCS4A01G411200 & $\begin{array}{l}\text { Chr4A:683800842- } \\
\text { 683801246 }\end{array}$ & 405 & 134 & 14461.68 & 10.61 & 1 \\
\hline TaVQ24 & TraesCS4A01G411300 & $\begin{array}{l}\text { Chr4A:683805840- } \\
\text { 683806277 }\end{array}$ & 438 & 145 & 15124.32 & 10.9 & 1 \\
\hline TaVQ25 & TraesCS4B01G178500 & $\begin{array}{l}\text { Chr4B:391157880- } \\
391158956\end{array}$ & 438 & 145 & 14849.46 & 7.1 & 1 \\
\hline TaVQ26 & TraesCS4B01G311200 & $\begin{array}{l}\text { Chr4B:601276598- } \\
\text { 601277606 }\end{array}$ & 435 & 144 & 14860.96 & 11.14 & 1 \\
\hline TaVQ27 & TraesCS4B01G311300 & $\begin{array}{l}\text { Chr4B:601284457- } \\
\text { 601284921 }\end{array}$ & 465 & 154 & 16000.23 & 10.55 & 1 \\
\hline TaVQ28 & TraesCS4B01G311400 & $\begin{array}{l}\text { Chr4B:601306252- } \\
\text { 601306716 }\end{array}$ & 465 & 154 & 16004.18 & 10.55 & 1 \\
\hline TaVQ29 & TraesCS4D01G180100 & $\begin{array}{l}\text { Chr4D:313885547- } \\
313886431\end{array}$ & 450 & 149 & 15190.79 & 8.01 & 1 \\
\hline TaVQ30 & TraesCS4D02G021000 & $\begin{array}{l}\text { Chr4D:8997650- } \\
8998244\end{array}$ & 1002 & 333 & 26481.38 & 5.19 & 1 \\
\hline TaVQ31 & TraesCS5A01G010900 & $\begin{array}{l}\text { Chr5A:7167768- } \\
\text { 7168166 }\end{array}$ & 399 & 132 & 14359.52 & 10.15 & 1 \\
\hline TaVQ32 & TraesCS5A01G027100 & $\begin{array}{l}\text { Chr5A:22485164- } \\
22486133\end{array}$ & 759 & 252 & 26758.28 & 9.44 & 1 \\
\hline TaVQ33 & TraesCS5A01G189700 & $\begin{array}{l}\text { Chr5A:393252902- } \\
\text { 393254173 }\end{array}$ & 1272 & 423 & 42945.76 & 6.55 & 1 \\
\hline TaVQ34 & TraesCS5A01G427000 & $\begin{array}{l}\text { Chr5A:611817416- } \\
\text { 611818023 }\end{array}$ & 444 & 147 & 15224.72 & 9.56 & 1 \\
\hline TaVQ35 & TraesCS5B01G008700 & $\begin{array}{l}\text { Chr5B:9243595- } \\
\text { 9244008 }\end{array}$ & 414 & 137 & 14803.08 & 9.88 & 1 \\
\hline TaVQ36 & TraesCS5B01G026300 & $\begin{array}{l}\text { Chr5B:25061684- } \\
\text { 25062761 }\end{array}$ & 732 & 243 & 25550.96 & 9.51 & 1 \\
\hline TaVQ37 & TraesCS5B01G193500 & $\begin{array}{l}\text { Chr5B:349712051- } \\
349713313\end{array}$ & 1263 & 420 & 42784.59 & 6.37 & 1 \\
\hline TaVQ38 & TraesCS5B01G428900 & $\begin{array}{l}\text { Chr5B:604226071- } \\
\text { 604227208 }\end{array}$ & 444 & 147 & 15152.49 & 9.56 & 1 \\
\hline TaVQ39 & TraesCS5B01G503300 & $\begin{array}{l}\text { Chr5B:669909164- } \\
669909637\end{array}$ & 474 & 157 & 16299.42 & 11.29 & 1 \\
\hline
\end{tabular}




\begin{tabular}{|c|c|c|c|c|c|c|c|}
\hline Name & Gene ID & Location & $\begin{array}{l}\text { ORF } \\
\text { length(bp) }\end{array}$ & $\begin{array}{l}\text { Size } \\
\text { (aa) }\end{array}$ & $\mathrm{MW}(\mathrm{Da})$ & pl & Exons \\
\hline TaVQ40 & TraesCS5D01G015700 & $\begin{array}{l}\text { Chr5D:9068493- } \\
\text { 9069444 }\end{array}$ & 399 & 132 & 14358.51 & 10.15 & 1 \\
\hline TaVQ41 & TraesCS5D01G034800 & $\begin{array}{l}\text { Chr5D:34043996- } \\
\text { 34045414 }\end{array}$ & 735 & 244 & 25783.27 & 9.09 & 1 \\
\hline TaVQ42 & TraesCS5D01G201200 & $\begin{array}{l}\text { Chr5D:304876446- } \\
304878167\end{array}$ & 1722 & 573 & 59359.24 & 10.4 & 1 \\
\hline TaVQ43 & TraesCS5D01G434900 & $\begin{array}{l}\text { Chr5D:490166006- } \\
\text { 490166449 }\end{array}$ & 444 & 147 & 15110.47 & 9.56 & 1 \\
\hline TaVQ44 & TraesCS6A01G156200 & $\begin{array}{l}\text { Chr6A:145133789- } \\
\text { 145134454 }\end{array}$ & 666 & 221 & 22431.63 & 9.85 & 1 \\
\hline TaVQ45 & TraesCS6A01G300700 & $\begin{array}{l}\text { Chr6A:533466786- } \\
\text { 533467235 }\end{array}$ & 450 & 149 & 15970.96 & 10.16 & 1 \\
\hline TaVQ46 & TraesCS6A01G301100 & $\begin{array}{l}\text { Chr6A:534747170- } \\
\text { 534747685 }\end{array}$ & 516 & 171 & 17845.92 & 9.49 & 1 \\
\hline TaVQ47 & TraesCS6B01G184400 & $\begin{array}{l}\text { Chr6B:207154528- } \\
207155778\end{array}$ & 681 & 226 & 23005.3 & 10.08 & 1 \\
\hline TaVQ48 & TraesCS6B01G330400 & $\begin{array}{l}\text { Chr6B:579549916- } \\
\text { 579550626 }\end{array}$ & 492 & 163 & 17065 & 9.2 & 1 \\
\hline TaVQ49 & TraesCS6D01G146200 & $\begin{array}{l}\text { Chr6D:116952516- } \\
116953190\end{array}$ & 675 & 224 & 22649.97 & 9.85 & 1 \\
\hline TaVQ50 & TraesCS6D01G280600 & $\begin{array}{l}\text { Chr6D:388136875- } \\
388137396\end{array}$ & 522 & 173 & 18231.26 & 9.2 & 1 \\
\hline TaVQ51 & TraesCS7A01G326900 & $\begin{array}{l}\text { Chr7A:475165941- } \\
\text { 475166708 }\end{array}$ & 768 & 255 & 26443.91 & 10.07 & 1 \\
\hline TaVQ52 & TraesCS7A01G349400 & $\begin{array}{l}\text { Chr7A:512169425- } \\
\text { 512169814 }\end{array}$ & 390 & 129 & 13377.16 & 9.45 & 1 \\
\hline TaVQ53 & TraesCS7A01G375900 & $\begin{array}{l}\text { Chr7A:549001358- } \\
\text { 549001981 }\end{array}$ & 603 & 200 & 21229.86 & 10.61 & 1 \\
\hline TaVQ54 & TraesCS7A01G401900 & $\begin{array}{l}\text { Chr7A:581344730- } \\
\text { 581345350 }\end{array}$ & 621 & 206 & 22373.4 & 6.07 & 1 \\
\hline TaVQ55 & TraesCS7A01G478700 & $\begin{array}{l}\text { Chr7A:671483204- } \\
\text { 671483848 }\end{array}$ & 645 & 214 & 21698.87 & 9.51 & 1 \\
\hline TaVQ56 & TraesCS7B01G227600 & $\begin{array}{l}\text { Chr7B:427821922- } \\
\text { 427822689 }\end{array}$ & 768 & 255 & 26484.95 & 9.77 & 1 \\
\hline TaVQ57 & TraesCS7B01G233400 & $\begin{array}{l}\text { Chr7B:436838688- } \\
\text { 436839071 }\end{array}$ & 384 & 127 & 13522.39 & 8.91 & 1 \\
\hline TaVQ58 & TraesCS7B01G277500 & $\begin{array}{l}\text { Chr7B:507836057- } \\
\text { 507836671 }\end{array}$ & 615 & 204 & 21621.29 & 10.39 & 1 \\
\hline TaVQ59 & TraesCS7B01G302000 & $\begin{array}{l}\text { Chr7B:538864067- } \\
\text { 538864690 }\end{array}$ & 624 & 207 & 22455.42 & 5.97 & 1 \\
\hline
\end{tabular}




\begin{tabular}{|llllllll|}
\hline Name & Gene ID & Location & $\begin{array}{l}\text { ORF } \\
\text { length(bp) }\end{array}$ & $\begin{array}{l}\text { Size } \\
\text { (aa) }\end{array}$ & MW(Da) & pl & Exons \\
\hline TaVQ60 & TraesCS7B01G381400 & $\begin{array}{l}\text { Chr7B:646209297- } \\
\text { 646210514 }\end{array}$ & 627 & 208 & 21214.45 & 9.51 & 1 \\
\hline TaVQ61 & TraesCS7D01G323700 & $\begin{array}{l}\text { Chr7D:413441710- } \\
\text { 413442474 }\end{array}$ & 765 & 254 & 26249.67 & 9.63 & 1 \\
\hline TaVQ62 & TraesCS7D01G329300 & $\begin{array}{l}\text { Chr7D:420782426- } \\
\text { 420782812 }\end{array}$ & 387 & 128 & 13671.46 & 8.93 & 1 \\
\hline TaVQ63 & TraesCS7D01G372400 & $\begin{array}{l}\text { Chr7D:481836636- } \\
\text { 481837615 }\end{array}$ & 477 & 158 & 16567.59 & 10.19 & 1 \\
\hline TavQ64 & TraesCS7D01G395700 & $\begin{array}{l}\text { Chr7D:510450077- } \\
\text { 510450709 }\end{array}$ & 636 & 211 & 22939.95 & 5.67 & 1 \\
\hline TaVQ65 & TraesCS7D01G466100 & $\begin{array}{l}\text { Chr7D:579961244- } \\
\text { 579961867 }\end{array}$ & 624 & 207 & 21039.19 & 9.3 & 1 \\
\hline
\end{tabular}

\section{Phylogenetic trees of VQ proteins from wheat, maize, rice, and Arabidopsis}

To explore the evolutionary relationships among $V Q$ genes from wheat, Arabidopsis, rice, and maize, we downloaded published VQ protein sequences from these species (Table S1) [8-10] and constructed a phylogenetic tree (Fig. 1). Based on the original division and naming of $V Q$ subfamilies in Arabidopsis and rice, we divided the 200 VQ genes (34 AtVQ genes, 40 OsVQ genes, $61 \mathrm{ZmVQ}$ genes, and 65 TaVQ genes) into seven subfamilies (VQI, VQII, VQIII, VQIV, VQV, VQVI, and VQVII). The VQII subfamily contained the largest number of genes (28) (Fig. 1). Members of the VQ family from rice, maize, and wheat, which belong to the Gramineae, were interspersed, while those of Arabidopsis, a model plant from the Cruciferae, formed separate clades, probably due to the relatively distant relationship between monocots and dicots.

\section{Structural analysis of the VQ gene family}

We constructed a wheat $V Q$ phylogenetic tree and a gene structure diagram (Fig. 2a). The structure of each $V Q$ gene contained one to three parts: the untranslated region (yellow rectangle), the exon region (green rectangle), and the intron region (solid gray line). Among the 48 TaVQ paralogous pairs (Table 2), only two pairs (TaVQ10/-17 and TaVQ53/-58) differed in intron number, having lost or gained one intron (Fig. 2A and Table S2). Further analysis revealed that $94 \%$ of the TaVQ genes had no introns, and only four genes (TaVQ13/-17/-18/-53) contained one intron. This result is consistent with previous studies in other species: $78 \%, 88 \%, 89 \%$ and $93 \%$ of the $V Q$ genes in poplar, Arabidopsis, maize, and rice have no introns, respectively, whereas only $28 \%$ of moss $V Q$ genes have no introns (Fig. 2b). Based on comparisons of many species, including angiosperms (rice, poplar, soybean, Chinese cabbage, etc.) and bryophytes (moss), we speculate that most $V Q$ genes tend to lose introns during long-term evolution $[6,8,9,43,44]$. 
Table 2

Paralogous ( $\mathrm{Ta} / \mathrm{Ta}$ ) and orthologous ( $\mathrm{Ta} / \mathrm{Os}$ and $\mathrm{Ta} / \mathrm{Zm}$ ) genes pairs.

\begin{tabular}{|c|c|c|}
\hline Paralogous & Orthologous & \\
\hline TaVQ1/TaVQ4 & TaVQ1/OsVQ8 & TaVQ1/ZmVQ14 \\
\hline TaVQ1/TaVQ7 & TaVQ1/OsVQ15 & TaVQ1/ZmVQ59 \\
\hline TaVQ3/TaVQ6 & TaVQ3/OsVQ16 & TaVQ4/ZmVQ14 \\
\hline TaVQ3/TaVQ9 & TaVQ4/OsVQ15 & TaVQ4/ZmVQ59 \\
\hline TaVQ4/TaVQ7 & TaVQ6/OsVQ16 & TaVQ6/ZmVQ13 \\
\hline TaVQ6/TaVQ9 & TaVQ7/OsVQ8 & TaVQ7/ZmVQ14 \\
\hline TaVQ10/TaVQ17 & TaVQ7/OsVQ15 & TaVQ7/ZmVQ59 \\
\hline TaVQ11/TaVQ14 & TaVQ9/OsVQ16 & TaVQ32/ZmVQ30 \\
\hline TaVQ11/TaVQ19 & TaVQ10/OsVQ12 & TaVQ41/ZmVQ30 \\
\hline TaVQ12/TaVQ15 & TaVQ17/OsVQ12 & TaVQ53/ZmVQ35 \\
\hline TaVQ13/TaVQ18 & TaVQ26/OsVQ26 & TaVQ53/ZmVQ51 \\
\hline TaVQ14/TaVQ19 & TaVQ32/OsVQ8 & TaVQ58/ZmVQ35 \\
\hline TaVQ21/TaVQ39 & TaVQ33/OsVQ35 & TaVQ58/ZmVQ51 \\
\hline TaVQ22/TaVQ23 & TaVQ36/OsVQ8 & TaVQ63/ZmVQ35 \\
\hline TaVQ22/TaVQ26 & TaVQ37/OsVQ35 & \\
\hline TaVQ22/TaVQ27 & TaVQ41/OsVQ8 & \\
\hline TaVQ22/TaVQ28 & TaVQ44/OsVQ5 & \\
\hline TaVQ22/TaVQ30 & TaVQ47/OsVQ5 & \\
\hline TaVQ24/TaVQ26 & TaVQ49/OsVQ5 & \\
\hline TaVQ24/TaVQ27 & TaVQ53/OsVQ23 & \\
\hline TaVQ24/TaVQ28 & TaVQ58/OsVQ23 & \\
\hline TaVQ24/TaVQ30 & TaVQ63/OsVQ23 & \\
\hline \multicolumn{3}{|l|}{ TaVQ26/TaVQ27 } \\
\hline \multicolumn{3}{|l|}{ TaVQ26/TaVQ28 } \\
\hline \multicolumn{3}{|l|}{ TaVQ26/TaVQ30 } \\
\hline \multicolumn{3}{|l|}{ TaVQ27/TaVQ28 } \\
\hline \multicolumn{3}{|l|}{ TaVQ27/TaVQ30 } \\
\hline \multicolumn{3}{|l|}{ TaVQ27/TaVQ39 } \\
\hline TaVQ28/TaVQ30 & & \\
\hline
\end{tabular}




\begin{tabular}{|c|}
\hline Orthologous \\
\hline TaVQ28/TaVQ39 \\
\hline TaVQ32/TaVQ36 \\
\hline TaVQ32/TaVQ41 \\
\hline TaVQ33/TaVQ37 \\
\hline TaVQ33/TaVQ42 \\
\hline TaVQ36/TaVQ41 \\
\hline TaVQ37/TaVQ42 \\
\hline TaVQ44/TaVQ47 \\
\hline TaVQ44/TaVQ49 \\
\hline TaVQ47/TaVQ49 \\
\hline TaVQ51/TaVQ56 \\
\hline TaVQ51/TaVQ61 \\
\hline TaVQ53/TaVQ58 \\
\hline TaVQ54/TaVQ59 \\
\hline TaVQ55/TaVQ60 \\
\hline TaVQ55/TaVQ65 \\
\hline TaVQ56/TaVQ61 \\
\hline TaVQ59/TaVQ64 \\
\hline TaVQ60/TaVQ65 \\
\hline
\end{tabular}

Using published information on characteristics of the VQ domain as a reference, we aligned the protein sequences of wheat and analyzed their VQ domains. The 65 TaVQ proteins all contained conserved VQ domains, but they differed slightly and could be grouped into three types: FxxxVQxLTG (52/65), FxxxVQxFTG (10/65), and FxxxVQxITG (3/65) (Fig. 3a). We further analyzed the VQ domains from multiple species (Fig. 3b) and found that the FxxxVQxLTG sequence was most prevalent and that two additional VQ domain types (LTG/FTG) were also common. There were differences in VQ domain sequence between monocots and dicots. In addition to the more common domain sequences, monocot VQ domains also included ITG, ATG, and LTA, and dicot VQ domains included LTS, LTD, YTG, LTR, and LTV (Table S3).

A total of 20 conserved motifs were identified in the TaVQ gene family (Table S4). All 65 TaVQ proteins shared one conserved motif (core motif 1, Motif 1) (Fig. 3c). The MEME diagram showed that wheat $V Q$ genes from the same subfamily tended to share the same conserved motifs. Only 7 of the 48 TaVQ paralogous pairs (TaVQ12/-15, TaVQ32/-36, TaVQ32/-41, TaVQ44/-49, TaVQ47/-49, TaVQ55/-60, and TaVQ60/-65) differed in their motifs.

\section{Evolution and divergence of the VQ gene family in wheat, rice, and maize}


In total, 48 homologous pairs were identified in wheat, 22 in wheat and rice, and 14 in wheat and maize (Table 2). The Ks values of the wheat paralogous pairs ranged from 0.0163 to 1.5197 , indicating that the occurrence of the duplication event in this species was approximately 1.2538 to 116.8985 MYA. The Ks values of orthologous pairs from wheat and rice ranged from 0.5821 to 1.6479 , indicating that duplication events occurred approximately

44.78 to 126.7631 MYA. The Ks values of orthologous pairs from wheat and maize ranged from 0.6453 to 1.0257 , indicating that the duplication events occurred approximately 49.6415 to 78.8962 MYA (Table 3). 
Table 3

$\mathrm{Ka}, \mathrm{Ks}$ and $\mathrm{Ka} / \mathrm{Ks}$ ratios of Paralogous and orthologous pairs

\begin{tabular}{|c|c|c|c|c|}
\hline Pairs & $\mathrm{Ka}$ & Ks & $\mathrm{Ka} / \mathrm{Ks}$ & Date(MYA) \\
\hline TaVQ1/TaVQ4 & 0.0127 & 0.1185 & 0.1070 & 9.1162 \\
\hline TaVQ1/TaVQ7 & 0.0070 & 0.0894 & 0.0790 & 6.8792 \\
\hline TaVQ3/TaVQ6 & 0.0240 & 0.0751 & 0.3200 & 5.7800 \\
\hline TaVQ3/TaVQ9 & 0.3823 & 0.2480 & 1.5420 & 19.0754 \\
\hline TaVQ4/TaVQ7 & 0.0085 & 0.0935 & 0.0900 & 7.1931 \\
\hline TaVQ6/TaVQ9 & 0.3781 & 0.2406 & 1.5720 & 18.5046 \\
\hline TaVQ10/TaVQ17 & 0.0448 & 0.0747 & 0.5990 & 5.7446 \\
\hline TaVQ11/TaVQ14 & 1.8069 & 0.9075 & 1.9910 & 69.8100 \\
\hline TaVQ11/TaVQ19 & 1.0034 & 0.6031 & 1.6640 & 46.3915 \\
\hline TaVQ12/TaVQ15 & 0.2352 & 0.1872 & 1.2560 & 14.4008 \\
\hline TaVQ13/TaVQ18 & 0.4955 & 0.3656 & 1.3550 & 28.1223 \\
\hline TaVQ14/TaVQ19 & 2.2662 & 0.9324 & 2.4310 & 71.7200 \\
\hline TaVQ21/TaVQ39 & 1.1545 & 0.9827 & 1.1750 & 75.5954 \\
\hline TaVQ22/TaVQ23 & 1.1107 & 0.9339 & 1.1890 & 71.8415 \\
\hline TaVQ22/TaVQ26 & 0.9021 & 0.8832 & 1.0210 & 67.9385 \\
\hline TaVQ22/TaVQ27 & 0.9769 & 0.8069 & 1.2110 & 62.0700 \\
\hline TaVQ22/TaVQ28 & 0.9796 & 0.8010 & 1.2230 & 61.6123 \\
\hline TaVQ22/TaVQ30 & 0.9757 & 0.8110 & 1.2030 & 62.3854 \\
\hline TaVQ24/TaVQ26 & 0.8192 & 0.8369 & 0.9790 & 64.3792 \\
\hline TaVQ24/TaVQ27 & 0.9598 & 0.8863 & 1.0830 & 68.1777 \\
\hline TaVQ24/TaVQ28 & 0.9475 & 0.8613 & 1.1000 & 66.2500 \\
\hline TaVQ24/TaVQ30 & 0.4472 & 0.4703 & 0.9510 & 36.1738 \\
\hline TaVQ26/TaVQ27 & 0.5848 & 0.5587 & 1.0470 & 42.9754 \\
\hline TaVQ26/TaVQ28 & 0.5786 & 0.5392 & 1.0730 & 41.4792 \\
\hline TaVQ26/TaVQ30 & 0.9816 & 0.9084 & 1.0810 & 69.8746 \\
\hline TaVQ27/TaVQ28 & 0.0059 & 0.0163 & 0.3640 & 1.2538 \\
\hline TaVQ27/TaVQ30 & 0.9130 & 0.8141 & 1.1210 & 62.6192 \\
\hline TaVQ27/TaVQ39 & 0.6100 & 0.4961 & 1.2300 & 38.1592 \\
\hline TaVQ28/TaVQ30 & 0.9005 & 0.7965 & 1.1310 & 61.2700 \\
\hline
\end{tabular}




\begin{tabular}{|c|c|c|c|c|}
\hline Pairs & $\mathrm{Ka}$ & Ks & $\mathrm{Ka} / \mathrm{Ks}$ & Date(MYA) \\
\hline TaVQ28/TaVQ39 & 0.6039 & 0.4944 & 1.2210 & 38.0331 \\
\hline TaVQ32/TaVQ36 & 0.9418 & 0.5073 & 1.8560 & 39.0254 \\
\hline TaVQ32/TaVQ41 & 0.8366 & 0.6503 & 1.2860 & 50.0215 \\
\hline TaVQ33/TaVQ37 & 1.3991 & 1.0467 & 1.3370 & 80.5123 \\
\hline TaVQ33/TaVQ42 & 2.5055 & 1.2491 & 2.0060 & 96.0877 \\
\hline TaVQ36/TaVQ41 & 0.8192 & 0.6094 & 1.3440 & 46.8800 \\
\hline TaVQ37/TaVQ42 & 2.1547 & 1.5197 & 1.4180 & 116.8985 \\
\hline TaVQ44/TaVQ47 & 0.2084 & 0.1818 & 1.1470 & 13.9815 \\
\hline TaVQ44/TaVQ49 & 0.2361 & 0.1606 & 1.4700 & 12.3569 \\
\hline TaVQ47/TaVQ49 & 0.2438 & 0.1783 & 1.3670 & 13.7138 \\
\hline TaVQ51/TaVQ56 & 0.2983 & 0.3403 & 0.8770 & 26.1769 \\
\hline TaVQ51/TaVQ61 & 0.2983 & 0.3403 & 0.8770 & 26.1769 \\
\hline TaVQ53/TaVQ58 & 1.4092 & 0.5952 & 2.3680 & 45.7823 \\
\hline TaVQ54/TaVQ59 & 0.9133 & 0.4927 & 1.8540 & 37.8962 \\
\hline TaVQ55/TaVQ60 & 1.2444 & 0.5470 & 2.2750 & 42.0762 \\
\hline TaVQ55/TaVQ65 & 1.2015 & 0.4813 & 2.4960 & 37.0231 \\
\hline TaVQ56/TaVQ61 & 0.1112 & 0.1833 & 0.6060 & 14.1023 \\
\hline TaVQ59/TaVQ64 & 1.0923 & 0.6707 & 1.6290 & 51.5885 \\
\hline TaVQ60/TaVQ65 & 0.1719 & 0.1390 & 1.2370 & 10.6892 \\
\hline TaVQ1/OsVQ8 & 2.7423 & 0.8121 & 3.3770 & 62.4654 \\
\hline TaVQ1/OsVQ15 & 1.7626 & 1.1060 & 1.5940 & 85.0769 \\
\hline TaVQ3/OsVQ16 & 2.7350 & 0.8081 & 3.3840 & 62.1623 \\
\hline TaVQ4/OsVQ15 & 1.7960 & 1.0882 & 1.6500 & 83.7077 \\
\hline TaVQ6/OsVQ16 & 2.5321 & 0.8356 & 3.0300 & 64.2731 \\
\hline TaVQ7/OsVQ8 & 2.6174 & 0.8540 & 3.0650 & 65.6892 \\
\hline TaVQ7/OsVQ15 & 1.7711 & 1.1700 & 1.5140 & 89.9977 \\
\hline TaVQ9/OsVQ16 & 2.1032 & 0.7993 & 2.6310 & 61.4815 \\
\hline TaVQ10/OsVQ12 & 1.5611 & 0.9874 & 1.5810 & 75.9523 \\
\hline TaVQ17/OsVQ12 & 1.5725 & 1.0693 & 1.4710 & 82.2562 \\
\hline TaVQ26/OsVQ26 & 1.8812 & 1.6479 & 1.1420 & 126.7631 \\
\hline
\end{tabular}




\begin{tabular}{|c|c|c|c|c|}
\hline Pairs & $\mathrm{Ka}$ & Ks & $\mathrm{Ka} / \mathrm{Ks}$ & Date(MYA) \\
\hline TaVQ32/OsVQ8 & 2.3258 & 0.8401 & 2.7680 & 64.6254 \\
\hline TaVQ33/OsVQ35 & 1.6720 & 0.9193 & 1.8190 & 70.7123 \\
\hline TaVQ36/OsVQ8 & 2.7247 & 1.0176 & 2.6780 & 78.2731 \\
\hline TaVQ37/OsVQ35 & 1.6260 & 0.8935 & 1.8200 & 68.7277 \\
\hline TaVQ41/OsVQ8 & 2.0860 & 0.9970 & 2.0920 & 76.6931 \\
\hline TaVQ44/OsVQ5 & 1.3857 & 0.6703 & 2.0670 & 51.5615 \\
\hline TaVQ47/OsVQ5 & 1.1333 & 0.6778 & 1.6720 & 52.1400 \\
\hline TaVQ49/OsVQ5 & 1.0462 & 0.5916 & 1.7680 & 45.5054 \\
\hline TaVQ53/OsVQ23 & 1.8754 & 0.6018 & 3.1160 & 46.2923 \\
\hline TaVQ58/OsVQ23 & 1.6660 & 0.5821 & 2.8620 & 44.7800 \\
\hline TaVQ63/OsVQ23 & 1.8612 & 0.7183 & 2.5910 & 55.2562 \\
\hline TaVQ1/ZmVQ14 & 1.7229 & 0.7294 & 2.3620 & 56.1085 \\
\hline TaVQ1/ZmVQ59 & 2.1932 & 0.9246 & 2.3720 & 71.1208 \\
\hline TaVQ4/ZmVQ14 & 1.8287 & 0.7525 & 2.4300 & 57.8877 \\
\hline TaVQ4/ZmVQ59 & 2.3077 & 0.9715 & 2.3750 & 74.7292 \\
\hline TaVQ6/ZmVQ13 & 1.9158 & 1.0257 & 1.8680 & 78.8962 \\
\hline TaVQ7/ZmVQ14 & 1.7985 & 0.7603 & 2.3660 & 58.4823 \\
\hline TaVQ7/ZmVQ59 & 2.3096 & 0.8740 & 2.6430 & 67.2292 \\
\hline TaVQ32/ZmVQ30 & 1.1674 & 0.8904 & 1.3110 & 68.4954 \\
\hline TaVQ41/ZmVQ30 & 2.1318 & 0.8361 & 2.5500 & 64.3131 \\
\hline TaVQ53/ZmVQ35 & 1.0682 & 0.6453 & 1.6550 & 49.6415 \\
\hline TaVQ53/ZmVQ51 & 2.1978 & 0.7752 & 2.8350 & 59.6277 \\
\hline TaVQ58/ZmVQ35 & 2.1378 & 0.8635 & 2.4760 & 66.4215 \\
\hline TaVQ58/ZmVQ51 & 1.3189 & 0.7664 & 1.7210 & 58.9500 \\
\hline TaVQ63/ZmVQ35 & 3.0729 & 0.7873 & 3.9030 & 60.5592 \\
\hline
\end{tabular}

To investigate the role of natural selection in the evolution of the $V Q$ gene family in Gramineae, we analyzed the $\mathrm{Ka} / \mathrm{Ks}$ ratios of all homologous pairs and generated sliding window graphs (Figure S1 and Table 3). Among the 48 paralogous pairs, 11 had $\mathrm{Ka} / \mathrm{Ks}$ ratios less than one, and 37 pairs had $\mathrm{Ka} / \mathrm{Ks}$ ratios greater than one, indicating that wheat $V Q$ genes were mainly subjected to positive selection during the evolutionary process. The Ka/Ks ratio of all orthologous pairs was greater than one, indicating that the VQ gene family in wheat, rice, and maize had primarily undergone positive selection. 


\section{Expression pattern analysis of the TaVQ gene family}

Transcriptome data (FPKM-values) were obtained for all TaVQ genes, with the exception of TaVQ13/-18/-45 (Fig. 4a and Table S5). The expression patterns of VQ genes differed among varieties and within time periods in the same variety. Most TaVQ genes were highly expressed in J411, especially at 4 hours after seed imbibition, and only four genes (TaVQ4/-7/-8/-20) were expressed at a low level. It is worth noting that TaVQ8 and TaVQ20 were both highly expressed in HMC21 and expressed at a low level in J411. We further analyzed the expression of 48 paralogous gene pairs. Only one pair showed similar expression patterns in both genes, whereas the rest were differentially expressed among varieties and within different time periods of the same variety.

Microarray data were obtained for 11 TaVQ genes to further investigate wheat $V Q$ gene expression (Fig. 4b and Table S6). TaVQ16, TaVQ31, and TaVQ35 were highly expressed in Aba and 22 DAP EM, but they showed little expression elsewhere. Further analysis of paralogous pairs showed that three pairs (TaVQ55/-60, TaVQ55/-65, and TaVQ60/-65) had similar expression patterns in different tissues.

\section{Promoter analysis and gene ontology annotation of the TaVQ gene family}

Two categories of response element were analyzed in the promoter regions of the TaVQ genes (Fig. 5a and Table S7). The first category included elements associated with biotic stress, including ABRE, CGTCA-motif, TGACGmotif, TGA-element, AuxRR-core, TCA-element, GARE-motif, and P-box. The second category included elements associated with abiotic stress, including MBS, LTR, and TC-rich repeats. The most common biotic stress response elements in the TaVQ promoters were associated with methyl jasmonate (CGTCA-motif and TGACG-motif) (42.77\%) and ABA (ABRE) (41.85\%) (Fig. 5b). The drought-associated MBS element (4.31\%) was the most common abiotic stress response element (Fig. 5c).

The 65 TaVQ genes were annotated with 15 GO terms (Fig. 6 and Table S8): three, three, and nine terms in the molecular function, cellular component, and biological process categories, respectively. Among these terms, G0:0005634 (cellular component), G0:0003674 (molecular function), and G0:0008150 (biological process) were most common and were assigned to 28,21 , and 13 genes, respectively.

\section{Chromosome locations and subcellular localization predictions for the TaVQ gene family}

The TaVQ genes were unevenly distributed on wheat chromosomes 1-7, and no TaVQ genes were present on chromosomes 1B and 1D (Figure S2). One gene was located on chromosome 1A, five were located on chromosomes 5B, 7A, 7B, and 7D, and two to four were located on each of the other chromosomes. Single gene cluster was a chromosomal region of less than $200 \mathrm{~Kb}$ containing two or more genes [45]. Two gene clusters containing six genes were identified on chromosomes 4A and 4B (Figure S2).

The TaVQ proteins were assigned to three locations by subcellular localization prediction analysis. Most of them were predicted to be located in the periplasmic region $(47,72.3 \%)$, some in the extracellular region $(15,23.1 \%)$, and the rest in the cytoplasmic region $(3,4.6 \%)$ (Table S9).

\section{Responses of TaVQ genes to water imbibition}

We investigated the responses of 65 TaVQ genes in six wheat varieties after water treatment (with different seed dormancy and germination phenotypes at 0 and $10 \mathrm{~h}$ ). Seeds from three highly dormant varieties (HMC21, YXM, and SNTT) showed no seed germination, whereas most seeds from three varieties with low dormancy (J411, 
ZY9507, and ZM895) germinated (average GI of 0.95, 0.92, and 0.94, respectively; Table S10) after $10 \mathrm{~h}$ of imbibition. We found that the TaVQ genes were differentially expressed in the six wheat varieties. The expression levels of 13 genes (TaVQ8/-9/-13/-17/-25/-32/-34/-43/-48/-49/-53/-59/-62) were higher in the low-dormancy varieties than in the high-dormancy varieties. Eight genes showed the opposite expression trend (TaVQ4/-16/-20/-35/-38/-42/-51/-56) (Fig. 7).

\section{Discussion}

The plant-specific VQ protein initially attracted attention due to its interaction with WRKY transcription factors [15]. Additional in-depth studies showed that the VQ gene family not only participated in responses to biotic and abiotic stress, but also was involved in the regulation of plant growth and development [5-7, 13-17]. Genome-wide surveys of VQ proteins have now been performed in a number of species, although functional research has remained focused on Arabidopsis. $V Q$ genes have not previously been characterized in wheat, and we therefore performed basic bioinformatics analyses to better understand the $V Q$ gene family in wheat.

We identified 65 VQ genes from wheat and classified them into seven subfamilies. The VQ genes of four species (wheat, rice, maize, and Arabidopsis) were distributed in each subfamily, but the number of members in each subfamily differed among species, indicating that the $V Q$ genes had developed in multiple directions over the course of evolution. The VQ genes of monocots (rice, corn and wheat) were interspersed and clustered together, whereas the $V Q$ genes of Arabidopsis were clustered into separate clades, indicating that proteins encoded by wheat VQ genes were highly similar to those of rice and maize [8-9]. These results highlight the evolutionary conservation of the $V Q$ gene family.

Phylogenetic trees represent the genetic relationships among gene families from different species and reflect the similarity of protein-coding genes. Combined with the structural analysis of the VQ gene family, we found that most VQ genes were intron-free [6, 8-11,43,44]. Based on comparisons of several species, we speculate that this gene family tends to lose introns during evolution. Amino acid sequence alignment and motif analysis indicated that the sequences of most VQ domains from different species were similar, although a small number of variants existed. In general, members of the same subfamily had similar types and numbers of conserved motifs, but there were also cases in which members of the same family had different types and numbers of conserved motifs. In addition, VQ had mutated to VH in the VQ domain of several Gramineae species $[5,6]$. Taken together, these results indicated that the $V Q$ gene family was highly conserved and diverse, reflecting the functional diversity of the gene family members.

With the development of next generation sequencing technology, the genomes of Arabidopsis, rice, maize, and wheat have recently been sequenced $[2,3,8-10]$. Their genome sizes are $164 \mathrm{Mb}, 389 \mathrm{Mb}, 2500 \mathrm{Mb}$, and $17 \mathrm{~Gb}$, respectively. Based on genome size and chromosome number, the number of $V Q$ genes among the four species is expected to be the highest in wheat, followed by maize, rice, and Arabidopsis. The numbers of maize, rice, and Arabidopsis VQ genes are 61, 40, and 34, and the number of wheat VQ genes in this study was 65, consistent with predictions based on genome size. By calculating the Ks value of homologous pairs to estimate the time of duplication events, the time range for whole genome duplication events in wheat was approximately 1.2538 to 116.8985 MYA. The Ka/Ks ratio of most paralogous pairs $(37,77 \%)$ was greater than one, indicating that the TaVQ gene family had undergone positive selection. The sliding window graph demonstrated that the Ka/Ks ratio of homologous pairs was different in different coding segments. There were segments greater than one and segments less than one, indicating that the homologous pairs had undergone different evolutionary selection 
pressures. These results show that natural selection plays an important role in the evolution and differentiation of the $V Q$ gene family.

TaVQ55/-60/-65 were highly expressed in GSC, GSR, GSE, SR, SL, Fba, and Pba, TaVQ2/-5/-8 were highly expressed in SL, Aba, 3-5 DAP C, and 22 DAP EM, and TaVQ16/-31/-35 were highly expressed in SL, Aba, and 22 DAP EM, indicating that the VQ gene family was active throughout multiple plant growth and development stages. Previous studies on Arabidopsis have shown that AtVQ14 regulates endosperm development and seed size (Wang et al., 2010) [20] ring time [9]. In this study, TaVQ48, which belongs to the same subfamily as AtVQ14/-29, was also expressed in floral bracts, before anthesis, in 22 DAP endosperm, and in 22 DAP embryos. Additionally, TaVQ48 was strongly expressed in germinating seeds, roots, seedling roots, and seedling leaves. These results point the way for further exploring the functions of the TaVQ gene family.

GO annotations of 62 TaVQ genes were extracted from transcriptome data. The most common GO terms were from the biological process category (43,38.1\%), especially G0:0006952 (13 genes) and G0:0008150 (15 genes). G0:0006952 is related to defense response, and combined with promoter analysis, we found that 5 TaVQ genes (TaVQ1/-2/-32/-41/-51) had this function in both analyses. G0:0010337 is related to the regulation of salicylic acid (SA) metabolism, but only TaVQ14 was assigned this annotation. TaVQ14 also had an SA cis-acting element in the promoter analysis. These results indicate that gene structure determines function, and the diversity of structure reflects the diversity of function.

Seed germination and dormancy are important traits in wheat production. They determine PHS resistance, thus affecting the yield and quality of wheat [46]. Identification of candidate genes that control seed dormancy and germination may help to minimize yield and quality losses caused by PHS. Abscisic acid (ABA) synthesis and sensitivity to $A B A$ are clearly involved in the onset of dormancy during seed maturation [47]. ABSCISIC ACIDINSENSITIVE5 (ABI5) is a central transcription factor in ABA signaling. Pan et al. (2018) [42] found that Arabidopsis VQ18 and VQ26 proteins interact with the ABI5 transcription factor to negatively modulate ABA response during seed germination. Decreasing the expression levels of $V Q 18$ and $V Q 26$ at the same time enhanced ABA signal transduction and thus inhibited seed germination, whereas overexpression of these two $V Q$ genes led to decreased ABA sensitivity of germinated seeds, confirming the regulatory role of VQ proteins, which act antagonistically with ABI5 to maintain appropriate ABA signaling levels and fine-tune seed germination. Nevertheless, the roles of the TaVQ gene remain largely unclear.

In the present study, we tested the 65 TaVQ genes expression during seed imbibition of six wheat varieties (HMC21, YXM, SNTT, J411, ZY9507 and ZM895). 13 TaVQ genes expression

( TaVQ8/-9/-13/-17/-25/-32/-34/-43/-48/-49/-53/-59/-62) were consistently higher in low-dormancy varieties than in high-dormancy varieties. By contrast, the expression levels of 8 TaVQ genes

( TaVQ4/-16/-20/-35/-38/-42/-51/-56) were consistently higher in high-dormancy varieties than in low-dormancy varieties. These $21 \mathrm{TaVQ}$ genes may be participate $d$ in the regulation of seed dormancy and germination.

According to the phylogenetic tree analysis, three of these 21 genes (TaVQ8, TaVQ13, and TaVQ59) are members of the VQV subfamily. Interestingly, Arabidopsis AtVQ18 and AtVQ26 involved in seed germination also belong to the VQV subfamily. These results suggest that TaVQ8/-13/-59 may have similar functions in the regulation of seed dormancy and germination, a hypothesis that requires future validation.

\section{Conclusions}


Phylogeny and diversification of $V Q$ genes in wheat were investigated from different levels, including phylogenetic tree construction and characterization of gene structures, conserved domains, chromosome positions, expression patterns, and promoter elements. In addition, we measured the expression levels of TaVQ genes in wheat varieties with contrasting seed dormancy and germination phenotypes by qRT-PCR to identify TaVQ gene family members that were potentially involved in seed dormancy and germination. Here, sixty-five TaVQ proteins were identified for the first time in common wheat, and bioinformatics analysis was performed to investigate their phylogenetic relationships and evolutionary divergence. The qRT-PCR data showed that 21 TaVQ candidate genes were potentially involved in seed dormancy and germination. These findings provide valuable information for further cloning and functional analysis of TaVQ genes, as well as useful candidate genes for improvement of PHS resistance in wheat.

\section{Methods}

\section{Plant Materials}

J411 (Jing 411), HMC21 (Hongmangchun 21), SNTT (Suiningtuotuo), ZM895 (Zhongmai 895), ZY9507 (Zhongyou 9507) and YXM (Yangxiaomai ) were selected to test the TaVQ gene expression pattern. Their average GI values were 0.96, 0.09, 0.15, 0.92, 0.97 and 0.07 (J411 and HMC21 were provided by Shihe Xiao, Chinese Academy of Agricultural Sciences. ZM895, ZY9507, YXM and SNTT are provided by Xianchun Xia from Chinese Academy of Agricultural Sciences.). The germination index was determined according to previous studies [46].

\section{Identification of wheat VQ genes}

To determine the number of $V Q$ genes in common wheat, we used sequences obtained from the Ensembl database (http://plants.ensembl.org/index.html) to build a local wheat database [46]. The VQ domain hidden Markov model (PF05678) was used to identify candidate genes by BLAST in the established local wheat database. To ensure the accuracy of the results, all candidate genes were inspected, repetitive sequences were removed, and Pfam, SMART, and $\mathrm{NCBI}$ online tools were used to verify the existence of the VQ conserved domain in all candidate genes [46, 48]. The ExPASy online tool was used to predict the isoelectric point (PI), protein molecular weight (MW), open reading frame (ORF), and other attributes of the VQ proteins.

\section{Phylogenetic tree and multiple sequence alignment}

FASTA sequence files were opened in ClustalX2.11 software [49-52] and used to generate a multiple sequence alignment from which a phylogenetic tree was constructed using the neighbor-joining method with 1000 bootstrap replicates in MEGA7.0 [43, 53-55]. The same method was used to build a composite phylogenetic tree of VQ protein sequences from corn, rice, Arabidopsis, and wheat.

\section{Intron/exon structure and conserved motif analysis}

The distribution and structure of exons and introns were determined by uploading CDS and genomic sequences to the Gene Structure Display Server (http://gsds.cbi.pku.edu.cn/) for plotting and analysis [7, 55, 56].

To predict structural differences among the TaVQ proteins, all candidate protein sequences were uploaded to the MEME online tool (http://memesuite.org/tools/meme) for conserved motif analysis using standard operating parameters $[55,57]$. 


\section{Identification of homologous pairs and calculation of $\mathrm{Ka} / \mathrm{Ks}$ values}

Using previously reported methods for the identification of homologous gene pairs (paralogs and orthologs), the nucleotide sequences of $V Q$ genes from wheat and other species were compared using BLASTN $[58,59]$.

Wheat homologous gene pairs were compared and aligned in ClustalX 2.11, and the aligned sequences were analyzed in MEGA7.0 [60]. The results were uploaded to DnaSP v5.10.1 [61] to calculate the values of Ka (non-

synonymous nucleotide mutation rate) and Ks (synonymous nucleotide mutation rate) for all homologous pairs. The formula $T=(\mathrm{Ks} / 2 \lambda) \times 10^{-6}$ was used to estimate the approximate dates of divergence events. To further analyze $\mathrm{Ka} / \mathrm{Ks}$ values, we used GraphPad Prism 5 software to generate a sliding window graph $[7,62]$. A Ka/Ks ratio less than 1 indicates that a DNA mutation is harmful and under purifying selection, whereas a $\mathrm{Ka} / \mathrm{Ks}$ ratio greater than 1 indicates that a DNA mutation is beneficial and under positive selection. A Ka/Ks ratio of 1 indicates neutral selection.

\section{Chromosome location and gene ontology annotation}

The chromosome location of TaVQ genes were downloaded from the Ensembl database, and chromosome maps were built using MapGene2Chromosome v2.0 [63].

Gene ontology (GO) annotations were assigned based on our transcriptome data (http://amigo.geneontology.org/amigo) in three types: biological_process, molecular_function and cellular_component [55].

\section{Promoter analysis and subcellular location prediction}

The 1500 bp sequence upstream of the transcription starting site of each VQ gene was downloaded from the Ensembl website, and the cis-acting elements in the promoter region were identified using the PlantCARE online tool [64]. WOLF was used to predict the subcellular localization of the TaVQ proteins [65].

\section{Tissue expression pattern analysis}

We collected three replicate seed tissue samples from HMC21 and $\mathrm{J} 411$ at 4, 6, and $10 \mathrm{~h}$ after seed imbibition for transcriptome sequencing. In addition, we obtained microarray data of 13 different tissues (three biological replicates) from the Gene Expression Omnibus database (https://www.ncbi.nlm.nih.gov/geo/) (accession number GSE12508) $[66,67]$. Thermapper Plus was used to generate an expression heat map $[45,68]$.

\section{RNA extraction and RT-qPCR analysis}

Total RNA was extracted from seeds using the TaKaRa MiniBEST Universal RNA Extraction Kit (Takara, Tokyo, Japan). Primer Premier 5.0 was used to design 65 TaVQ gene-specific primers, and TaActin was used as the reference gene [69]. The total PCR volume was $10 \mu \mathrm{l}$. The following is the reaction process $\nabla$ the first was denaturation at $94^{\circ} \mathrm{C}$ for $30 \mathrm{~s}$, then $40-45$ cycles for $5 \mathrm{~s}$ at $94^{\circ} \mathrm{C}, 15$ cycles at $50-60^{\circ} \mathrm{C}$, and finally an extension step at $72{ }^{\circ} \mathrm{C}$ for $10 \mathrm{~s}$. We performed three biological replicates for each sample. Finally, we process the data and create the figure by GraphPad version 5 [70].

\section{Abbreviations}


qRT-PCR, quantitative real-time PCR; Ks, number of synonymous substitutions per synonymous site; Ka, number of non-synonymous substitutions per non-synonymous site; CDS, coding sequence; bp, base pair; aa, amino acids; MW, molecular weight; Da, Dalton; PHS, Pre-harvest sprouting; GI, Germination index; pl, isoelectric point; GO, gene ontology; . GSC, germinating seed coleoptile; GSR, germinating seed root; GSE, germinating seed, embryo; SR, seedling root; SC, seedling crown; SL, seedling leaf; II, immature inflorescence; Fba, floral bracts before anthesis; Pba, pistil before anthesis; Aba, anthers before anthesis; 3-5 DAP C, 3-5 DAP caryopsis; 22 DAP EM, 22 DAP embryo; 22 DAP EN, 22 DAP endosperm.

\section{Declarations}

\section{Ethics approval and consent to participate}

Not applicable.

\section{Consent for publication}

\section{Availability of data and materials}

The genome sequences of wheat, maize, rice and Arabidopsis were downloaded from the Ensembl database (http://plants.ensembl.org/index.html), PlantTFDB (http://planttfdb.cbi.pku.edu.cn), Rice Genome Annotation Project database (http://rice.plantbiology.msu.edu/analyses_search_locus.shtml) and Arabidopsis Information Resource (http://www.arabidopsis.org).

\section{Competing Interests}

The authors declare that they have no competing interests.

\section{Funding}

This work was supported by grants from the National Natural Science Foundation of China (31871608), The China Agriculture Research System (CARS-03), The National key research and development plan "Breeding new wheat varieties with high-yielding, high-quality and water-saving in the south of Huang-Huai River winter wheat area" - the breeding of new wheat germplasm and varieties with resistance to adversity (2017YFD0100703), The breeding and industrialization of new wheat varieties with high yield and multi-resistance (18030701182), The National Key Research and Development Program of China (2016YFD0101802, 2017YFD0100804), Wheat Genetics and Breeding Research Platform Innovation Team of Anhui's University (2015-), Jiangsu Collaborative Innovation Center for Modern Crop Production (JCIC-MCP), and The Agriculture Research System of Anhui province (AHCYTX02).

These funding bodies had no role in the design of the study; in the collection, analyses, or interpretation of data; in the writing of the manuscript, and in the decision to publish the results. Publication costs are defrayed by these funding.

\section{Authors' contributions}

XRC and CG conceived the study, put into effect the main bioinformatics analyses, and drafted the manuscript. $D M X$ and $X L$ took part in the experiments and drafting of the manuscript. XP, WG, SNY, HY, JJC, XYM and JL 
processed the experimental data and helped to draft the manuscript. HPZ, CC, and CXM conceived and guided the experiments, and helped in coordinating the project and drafting the manuscript. All authors read and accepted the final manuscript.

\section{Acknowledgements}

We would like to thank TopEdit (www.topeditsci.com) for English language editing of this manuscript. Thanks to teachers Shihe Xiao and Xianchun Xia from the Chinese Academy of Agricultural Sciences for providing six pairs of parental germplasm.

\section{References}

1. Brenchley R, Spannagl M, Pfeifer M, Barker GLA, DAmore R, Allen AM, McKenzie N, Kramer M, Kerhornou A, and Dan B. Analysis of the bread wheat genome using whole genome shotgun sequencing. Nature,2012;491, 705-710.

2. Luo MC, Gu YQ, Puiu D, Wang H, Twardziok SO, Deal KR, Huo N, Zhu T, Wang L, Wang Y, McGuire PE, Liu S, Long $\mathrm{H}$, Ramasamy RK, et al. Genome sequence of the progenitor of the wheat D genome Aegilops tauschii. Nature,2007;551, 498-502.

3. Ling H, Ma B, Shi X, Liu H, Dong L, Sun H, Cao Y, Gao Q, Zheng S, Li Y, Yu Y, Du H, Qi M, Li Y, Lu H, Yu H, Cui Y, Wang N, et al. Genome sequence of the progenitor of wheat A subgenome Triticum urartu. Nature,2018;557, 424-428.

4. Pecher P, Eschen-Lippold L, Herklotz S, Kuhle K, Naumann K, Bethke G, Uhrig J, Weyhe M, Scheel D, and Lee J. The Arabidopsis thaliana mitogen-activated protein kinases MPK3 and MPK6 target a subclass of 'VQ-motif'containing proteins to regulate immune responses. New Phy,2014;203: 592-606.

5. Kim DY, Kwon SI, Choi C, Lee H, Ahn I, Park SR, Bae SC, Lee SC, and Hwang DJ. Expression analysis of rice VQ genes in response to biotic and abiotic stresses. Gene, 2013;529, 208-214.

6. Song W, Zhao H, Zhang X, Lei L, and Lai J. Genome-wide identification of VQ motif-containing proteins and their expression profiles under abiotic stresses in Maize. Front Plant Sci, 2016;6, 1177.

7. Wang Y, Liu H, Zhu D, Gao Y, Yan H, and Yan X. Genome-wide analysis of VQ motif-containing proteins in Moso bamboo (Phyllostachys edulis). Planta, 2017; 246, 165.

8. Cheng $Y$, and Chen Z. Structural and functional analysis of VQ motif-containing proteins in Arabidopsis as interacting proteins of WRKY transcription factors. Plant P,2012;159, 810-825.

9. Li N, Li X, Xiao J, and Wang S. Comprehensive analysis of VQ motif-containing gene expression in rice defense responses to three pathogens. Plant Cell Rep, 2014;33, 1493-1505.

10. Wang X, Zhang H, Sun G, Jin Y, and Qiu L. Identification of active VQ motif-containing genes and the expression patterns under low nitrogen treatment in soybean. Gene,2014;543, 237-243.

11. Wang M, Vannozzi A, Wang G, Zhong Y, Corso M, Cavallini E, and Cheng ZM. A comprehensive survey of the grapevine $V Q$ gene family and its transcriptional correlation with WRKY proteins. Front Plant Sci,2015;6, 417.

12. Schnable PS,Ware D, Fulton RS. The $B 73$ maize genome: complexity, diversity, and dynamics.

Science,2009;326, 1112-1115.

13. Perruc E, Charpenteau M, Ramirez BC, Jauneau A, Galaud JP, Ranjeva R, and Ranty B. A novel calmodulinbinding protein functions as a negative regulator of osmotic stress tolerance in Arabidopsis thaliana Plant 
J,2004;38, 410-420.

14. Cao J, Huang J, Yang Y, Hu X. Analyses of the oligopeptide transporter gene family in poplar and grape. BMC Genomics, 2011;12, 459-464.

15. Lai Z, Li Y, Wang F, Cheng Y, Fan B, Yu JQ, and Chen Z. Arabidopsis sigma factor binding proteins are activators of the WRKY33 transcription factor in plant defense. Plant Cell, 2011;23, 3824.

16. Hu Y, Chen L, Wang H, Zhang L, Wang F, and Yu D. Arabidopsis transcription factor WRKY\& functions antagonistically with its interacting partner VQ9 to modulate salinity stress tolerance. Plant J, 2013;74, 730745.

17. Zhang GY, Wang FD, Li JJ. Genome-wide identification and analysis of the $V Q$ motif-containing protein family in Chinese Cabbage (Brassica rapa ssp. Pekinensis). INTJ MOL SCI ,2015;16, 28683-28704.

18. Fill BK, Petersen M. Constitutive expression of MKS1confers susceptibility to Botrytis cinerea infection independent of PAD3 Plant Signaling Behavior, 2011;6, 1425-1427.

19. Hu P, Zhou W, Cheng Z, Fan M, Wang L, and Xie D. JAV1 controls jasmonate-regulated plant defense. Mol Cell, 2013;50, 504-515.

20. Wang A, Garcia D, Zhang H, Feng K, Chaudhury A, Berger F, Peacock WJ, Dennis ES, and Luo M. The VQ motif protein IKU1 regulates endosperm growth and seed size in Arabidopsis. Plant J,2010;63, 670-679.

21. Chen $\mathrm{CH}$ and Chen $\mathrm{ZX}$. Isolation and characterization of two pathogen- and salicylic acid-induced genes encoding WRKY DNA-binding proteins from tobacco. Plant Mol Biol,2000;42, 387-396.

22. Du $L$ and Chen $Z$. Identification of genes encoding receptor-like protein kinases as possible targets of pathogen- and salicylic acid-induced WRKY DNA-binding proteins in Arabidopsis. Plant J, 2000;24, 837-847.

23. Eulgem T, Rushton PJ, Robatzek $S$ and Somssich IE. The WRKY superfamily of plant transcription factors. Trends Plant Sci,2000;5, 199-206

24. Hara K, Yagi M, Kusano T and Sano H. Rapid systemic accumulation of transcripts encoding a tobacco WRKY transcription factor upon wounding. Mol Gen Genet, 2000;263, 30-37.

25. $\mathrm{Yu}$ D, Chen $\mathrm{C}$ and Chen Z. Evidence for an important role of WRKY DNA binding proteins in the regulation of NPR1 gene expression. Plant Cell,2001;13, 1527-1540.

26. Cormack RS, Eulgem T, Rushton PJ, Kochner P, Hahlbrock K and Somssich IE Leucine zipper-containing WRKY proteins widen the spectrum of immediate early elicitor-induced $W R K Y$ transcription factors in parsley. Biochim Biophys Acta,2002;1576, 92-100.

27. Pnueli L, Hallak-Herr E, Rozenberg M, Cohen M, Goloubinoff P, Kaplan A and Mittler R. Molecular and biochemical mechanisms associated with dormancy and drought tolerance in the desert legume Retama raetam. Plant J, 2002;31, 319-330.

28. Seki M, Narusaka M, Ishida J, Nanjo T, Fujita M, Oono Y, Kamiya A, Nakajima M, Enju A, Sakurai T, Satou M, Akiyama K, et al. Monitoring the expression profiles of 7000 Arabidopsis genes under drought, cold and highsalinity stresses using a full-length cDNA microarray. Plant J,2002;31, 279-292

29. Izaguirre MM, Scopel AL, Baldwin IT and Ballare CL. Convergent responses to stress. Solar ultraviolet-B radiation and Manduca sexta herbivory elicit overlapping transcriptional responses in field-grown plants of Nicotiana longiflora. Plant Physiol,2003;132, 1755-1767.

30. Guo ZJ, Kan YC, Chen XJ, Li DB and Wang DW. Characterization of a rice WRKY gene whose expression is induced upon pathogen attack and mechanical wounding. Acta Botanica Sinica, 2004;46, 955-964. 
31. Li J, Brader G and Palva ET. The WRKY70 transcription factor: a node of convergence for jasmonate-mediated and salicylatemediated signals in plant defense. Plant Cell, 2004;16, 319-331.

32. Xie Z, Zhang ZL, Zou X, Huang J, Ruas P, Thompson D and Shen QJ. Annotations and functional analyses of the rice WRKY gene superfamily reveal positive and negative regulators of abscisic acid signaling in aleurone cells. Plant Physiol,2005;137, 176-189.

33. Ralph S, Oddy C, Cooper D and Yueh H. Genomics of hybrid poplar (Populus trichocarpa 9 deltoides) interacting with forest tent caterpillars (Malacosoma disstria): normalized and fulllength cDNA libraries, expressed sequence tags, and a cDNA microarray for the study of insect-induced defences in poplar. Mol Ecol,2006;15, 1275-1297

34. Cui X, Yan Q, Gan S, Xue D, Wang H, Xing H, Guo N. GmWRKY40, a member of the WRKY transcription factor genes identified from Glycine max L., enhanced the resistance to Phytophthora sojae. BMC Plant Biol,2019;19, 1-15.

35. Kanofsky K, Riggers J, Staar M, Strauch CJ, Arndt LC, Hehl R. A strong NF-kB p65 responsive cis-regulatory sequence from Arabidopsis thaliana interacts with WRKY40. Plant Cell Rep,2019;38, 1139-1150.

36. Zhao K, Zhang D, Lv K, Zhang X, Cheng Z, Li R, Jiang T. Functional characterization of poplar WRKY75 in salt and osmotic tolerance. Plant Science,2019;289, 110259.

37. Khuman A, Arora S, Makkar H, Patel A, Chaudhary B. Extensive intragenic divergences amongst ancient WRKY transcription factor gene family is largely associated with their functional diversity in plants. Plant Gene, 2020;22, 100222.

38. Wang H, Zou S, Li Y, Lin F, Tang D. An ankyrin-repeat and WRKY-domain-containing immune receptor confers stripe rust resistance in wheat. Nat Commun, 2020;11, 1-11.

39. Andreasson E, Jenkins T, Brodersen P, Thorgrimsen S. The MAP kinase substrate MKS1 is a regulator of plant defense responses. EMBO J,2005;24, 2579-2589

40. Clerkx EJM, Vries HBD, Ruys GJ, Groot SPC, and Koornneef M. Characterization of green seed, an enhancer of abi3-1 in arabidopsis that affects seed longevity. Plant Physiol 132, 1077-1084.

41. Finkelstein R, Reeves W, and Ariizumi T. Molecular aspects of seed dormancy. Annual Rev Plant Biol, 2008;59, 387-415.

42. Pan JJ, Wang HP, Hu YR, Yu DQ. Arabidopsis VQ18 and VQ26 proteins interact with ABI5 transcription factor to negatively modulate ABA response during seed germination. Plant J, 2018;95, 529-544.

43. Chu W, Liu B, Wang Y, Pan F, Chen Z, Yan H, and Yan X. Genome-wide analysis of poplar VQ gene family and expression profiling under PEG, NaCl, and SA treatments. Tree Genet Genom,2016;12, 124.

44. Wang H, Hu Y, Pan J, and Yu D. Arabidopsis VQ motif-containing proteins VQ12 and VQ29 negatively modulate basal defense against Botrytis cinerea. Sci Rep,2015;5, 14185.

45. Sturn A, Quackenbush J, and Trajanoski Z. Genesis: cluster analysis of microarray data. Bioinformatics,2002;18, 207-208.

46. Cheng XR, Wang SX, Xu DM, Liu X, Zhang HP, Chang C, and Ma CX. Identification and analysis of the GASR gene family in common wheat (Triticum aestivum L.) and characterization of TaGASR34, a gene associated with seed dormancy and germination. Fron Genet,2019;4, 515.

47. Walker-Simmons M. ABA levels and sensitivity in developing wheat embryos of sprouting resistant and susceptible cultivars. Plant Physiol,1987;84, 61-66. 
48. Chen Z, Chen X, Yan H, Li W, Li YY, Cai R and Xiang Y. The lipoxygenase Gene Family in Poplar: identification, classification, and expression in response to MeJA treatment. PloS One,2015,10, e0125526.

49. Thompson JD, Gibson TJ, Plewniak F, and Higgins DG. The CLUSTAL_X windows interface: flexible strategies for multiple sequence alignment aided by quality analysis tools. Nucleic Acids Res,1995;25, 4876-4882.

50. Gao YM, Liu H, Wang Y, Li F, and Xiang Y. Genome-wide identification of PHD-fingergenes and expression pattern analysis under various treatments in moso bamboo (Phyllostachys edulis). Plant Physiol Bioch, 2017;123, S0981942817304357.

51. Cao Y, Han Y, Li D, Yi L, and Cai Y. MYB Transcription Factors in Chinese Pear (Pyrus bretschneideri Rehd.): Genome-wide identification, classification, and expression profiling during fruit development. Front Plant Sci, $2016 ; 7,557$.

52. Li Q, Li L, Liu Y, LY Q, Zhang H, Zhu J, and Li XJ. Influence of TaGW2-6a on seed development in wheat by negatively regulating gibberellin synthesis. Plant Science,2017;263, 226.

53. Saitou N, and Nei M. The neighbor-joining method: a new method for reconstructing phylogenetic trees. Molbiolevol,1987;4, 406-425.

54. Kumar S, Stecher G, and Tamura K. MEGA7: Molecular evolutionary genetics analysis version 7.0 for bigger datasets. Mol Biol Evol,2016;33, 1870-1874.

55. Cheng XR, Xiong R, Liu HL, Wu M, Chen F, Yan HW, and Xiang Y. Basic helix-loop-helix gene family: Genome wide identification, phylogeny, and expression in Moso bamboo. Plant physiol bioch,2018;132, 104-119.

56. Guo AY, Zhu QH, Chen X. GSDS:a gene structure display server. Hereditas, 2007;29,1023-1026.

57. Bailey TL, Boden M and Buske FA. MEME SUITE: tools for motif discovery and searching. Nucleic Acids Res,2009;37, W202-W208.

58. Altschul SF, Madden TL, Schäffer AA, Zhang J, Zhang Z, Miller W, and Lipman DJ. Gapped BLAST and PSIBLAST: a new generation of protein database search programs. Nucleic acids res,1997;25, 3389-3402.

59. Blanc G, and Wolfe KH. Widespread paleopolyploidy in model plant species inferred from age distributions of duplicate genes. Plant Cell,2004;16, 1667-1678.

60. Chen D, Chen Z, Wu M, Wang Y, Wang Y, Yan H, and Xiang Y. Genome-wide identification and expression analysis of the HD-Zip gene family in Moso Bamboo (Phyllostachys edulis). J Plant Grow Re,2017;36, 323337.

61. Librado P, and Rozas J. DnaSP v5: a software for comprehensive analysis of DNA polymorphism data. Bioinformatics,2009;25, 1451-1452.

62. Wang Y, Feng L, Zhu Y, Li Y, Yan H, and Xiang Y. Comparative genomic analysis of the WRKY III gene family in populus, grape, arabidopsis and rice. Biology Direct,2015;10, 48.

63. Voorrips RE. MapChart: Software for the graphical presentation of linkage maps and QTLs. Journal of Heredity,2002;93, 77-78.

64. Zhao P, Wang D, Wang R, Kong N, Zhang C, Yang C, Wu W, Ma H, and Chen Q. Genome-wide analysis of the potato $\mathrm{Hsp} 20$ gene family: identification, genomic organization and expression profiles in response to heat stress. BMC Genom,2018;19, 61.

65. Horton P, Park KJ, Obayashi T, Fujita N, Harada H, Adamscollier CJ, and Nakai K. WoLF PSORT: protein localization predictor. Nucleic Acids Res,2007;35, 585-587 
66. Barrett T, and Edgar R. Gene expression omnibus: microarray data storage, submission, retrieval, and analysis. Methods in Enzymol,2006;411, 352-369.

67. Wilkins O, Nahal H, Foong J, Provart NJ, and Campbell MM.Expansion and diversification of the Populus R2R3-MYB family of transcription factors. Plant Physiol,2009;149, 981-993.

68. Kiana T, Brady SM, Ryan A, Eugene L, and Provart NJ. The botany array resource: e-northerns, expression angling, and promoter analyses. Plant J, 2005;43, 153-163.

69. Sun T, Wang Y, Wang M, Li T, Zhou Y, Wang X, Wei S, He G, and Yang G. Identification and comprehensive analyses of the CBL and CIPK gene families in wheat (Triticum aestivum). BMC Plant Biol, 2015;15, 269.

70. Bryfczynski S. GraphPad: a CS2/CS7 tool for graph creation. Proceedings of the 47th Annual Southeast Regional Conference, Clemson, South Carolina, USA, 2009;March 19-21.

\section{Figures}




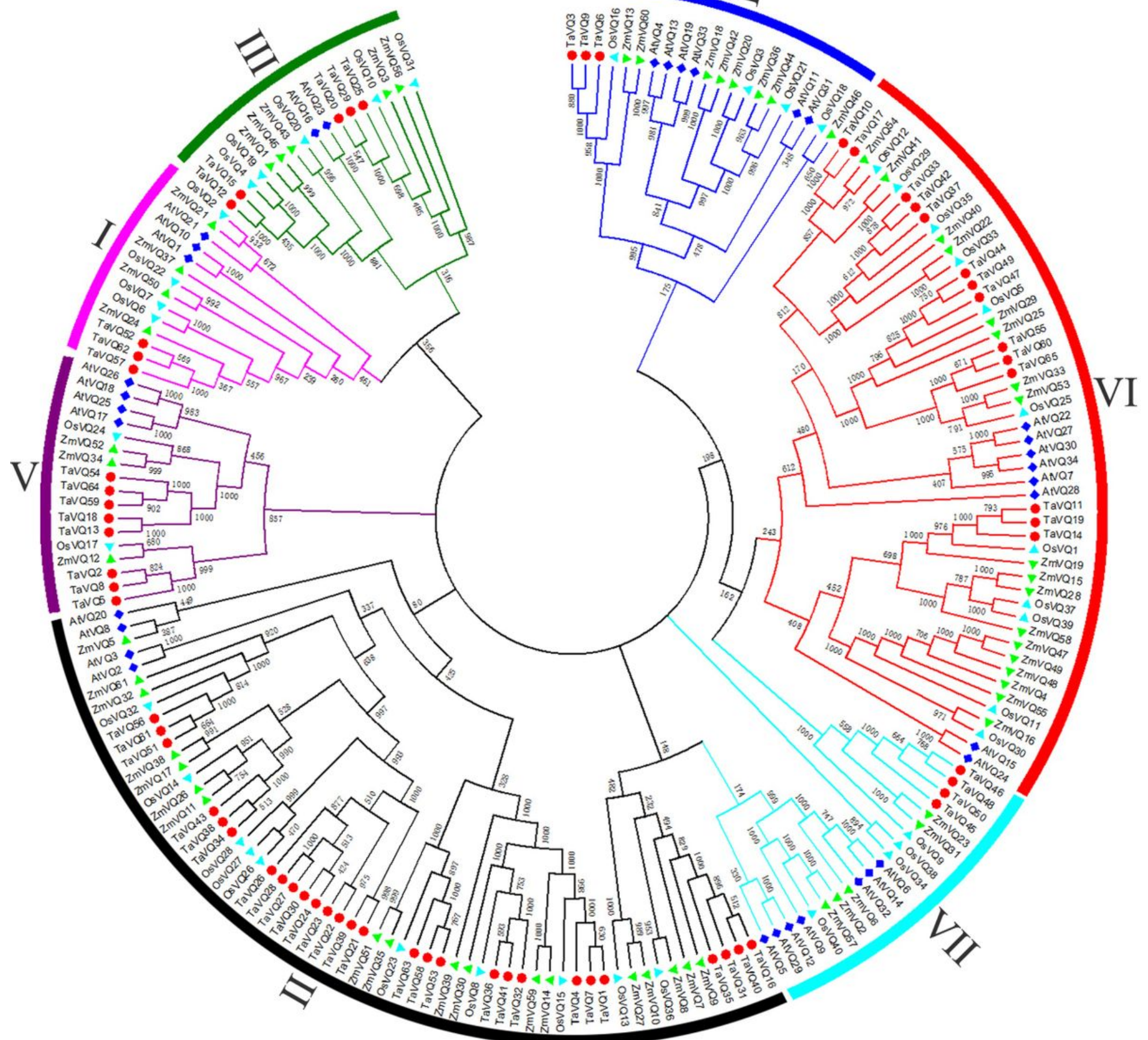

Figure 1

(caption not provided) 


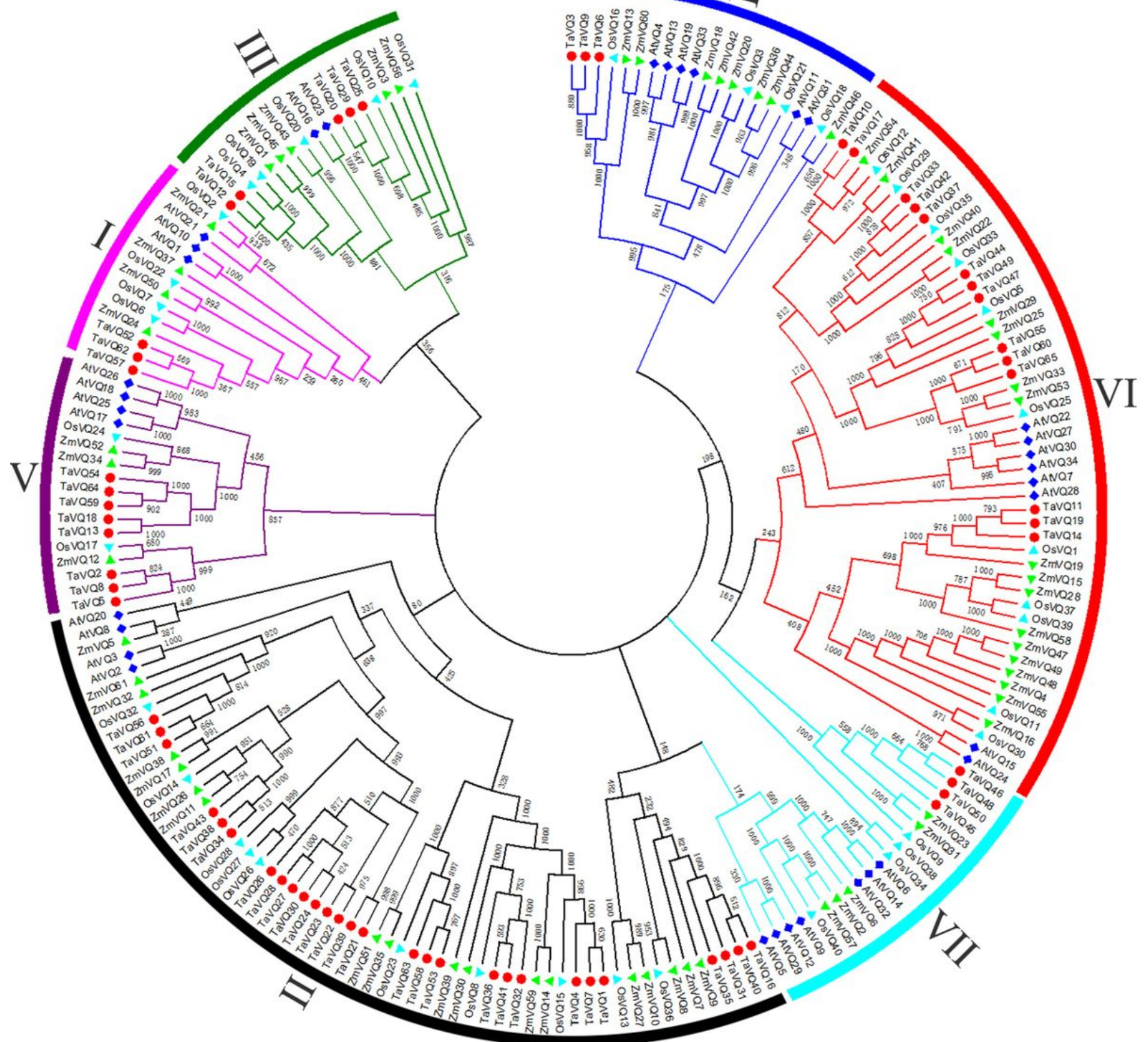

Figure 1

(caption not provided) 


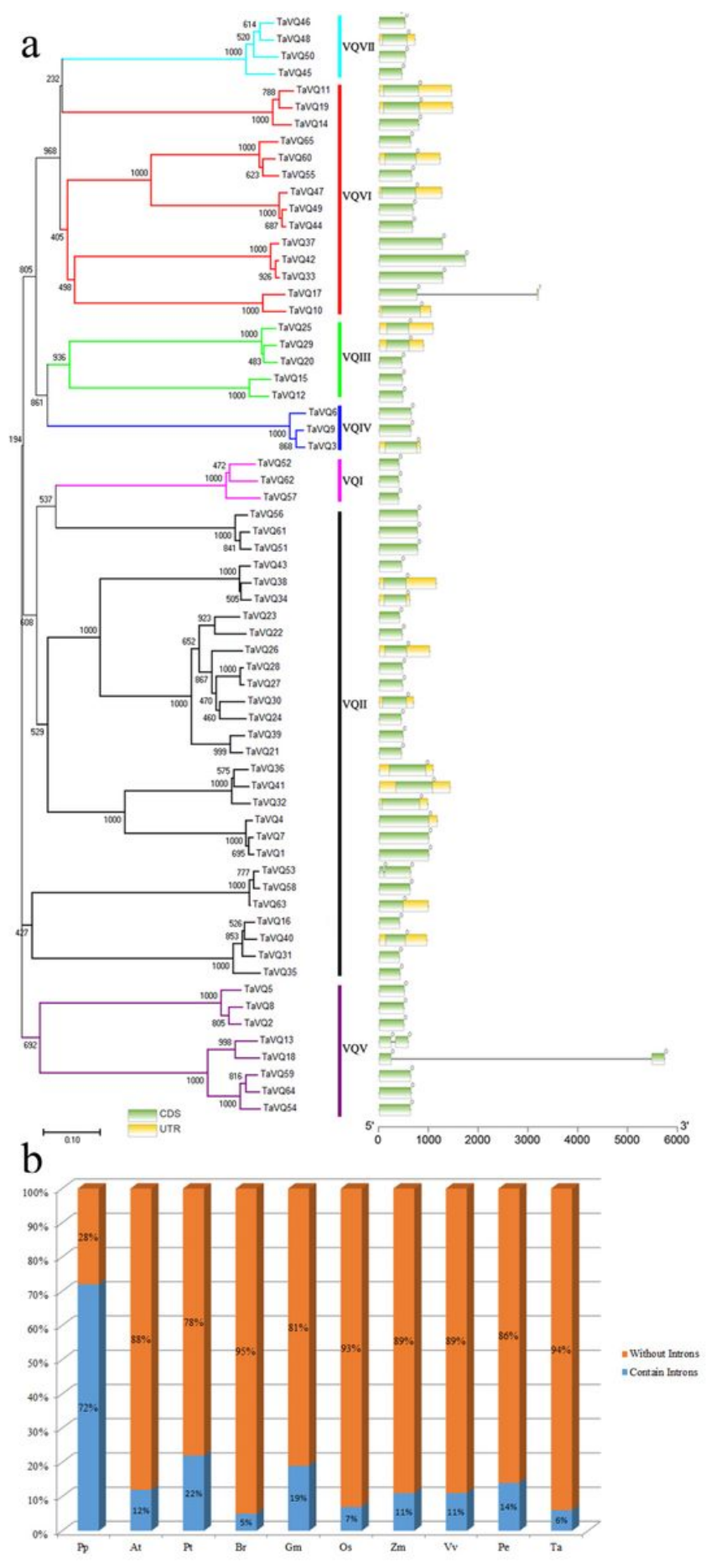

Figure 2

(caption not provided) 


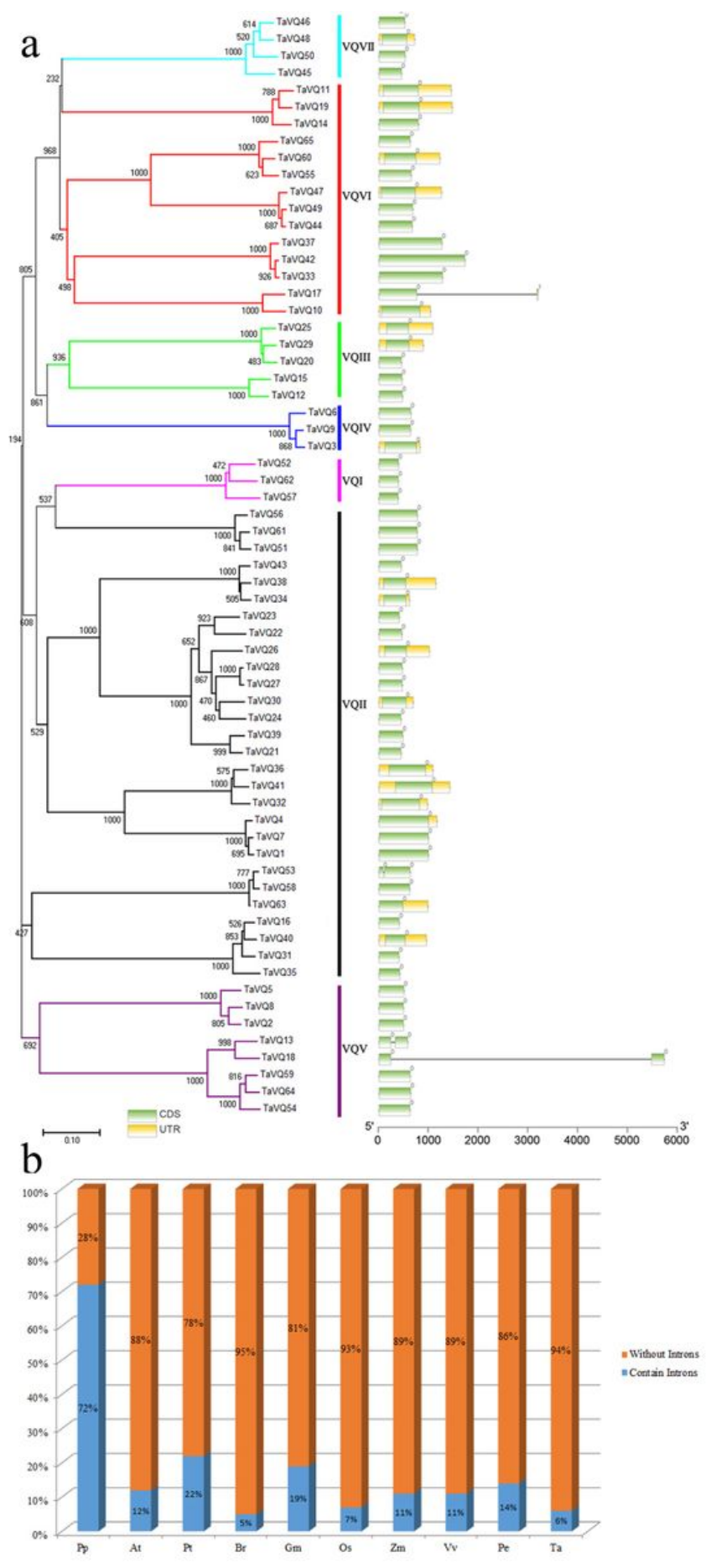

Figure 2

(caption not provided) 

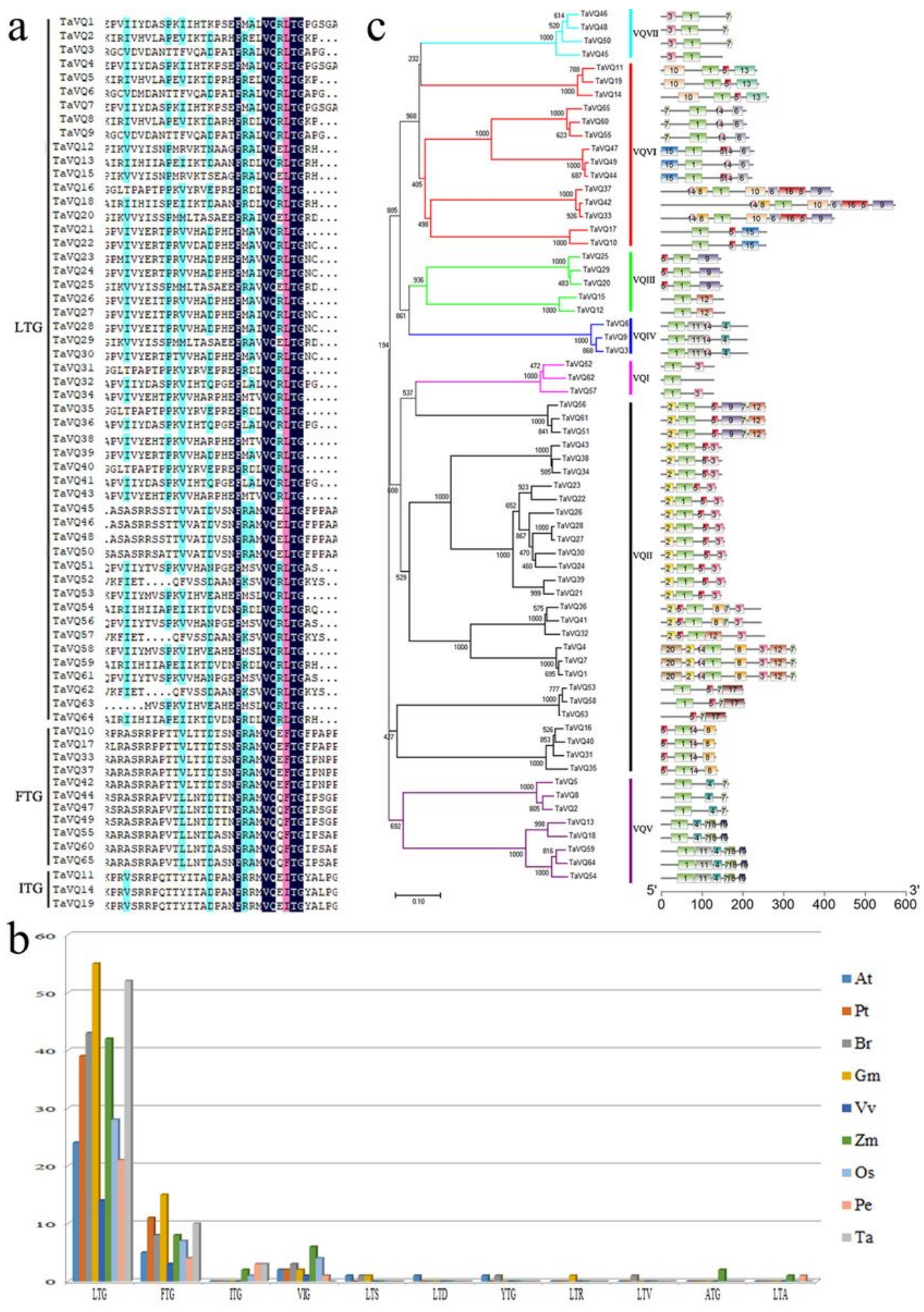

Figure 3

(caption not provided) 

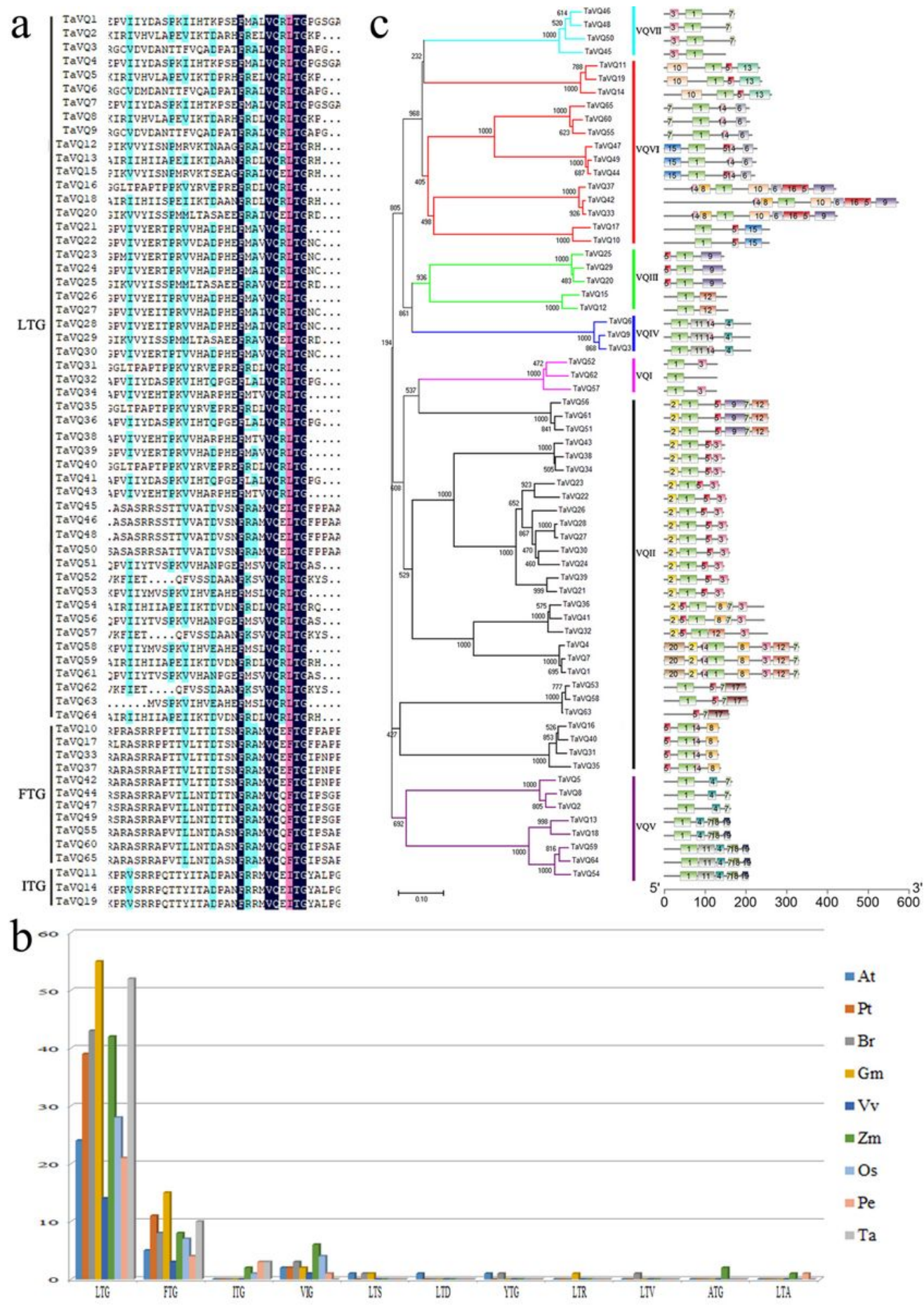

Figure 3

(caption not provided) 


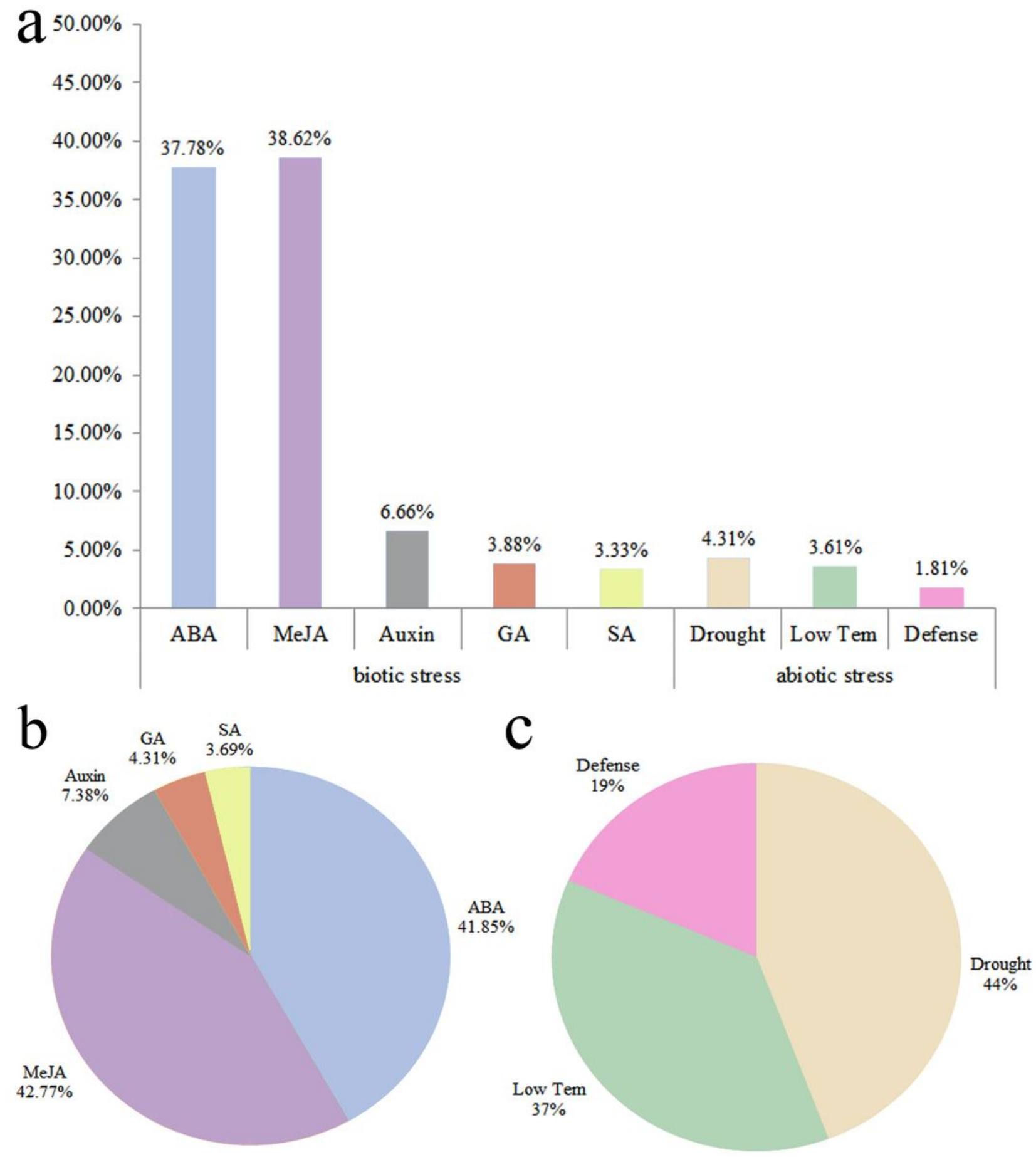

Figure 4

(caption not provided) 


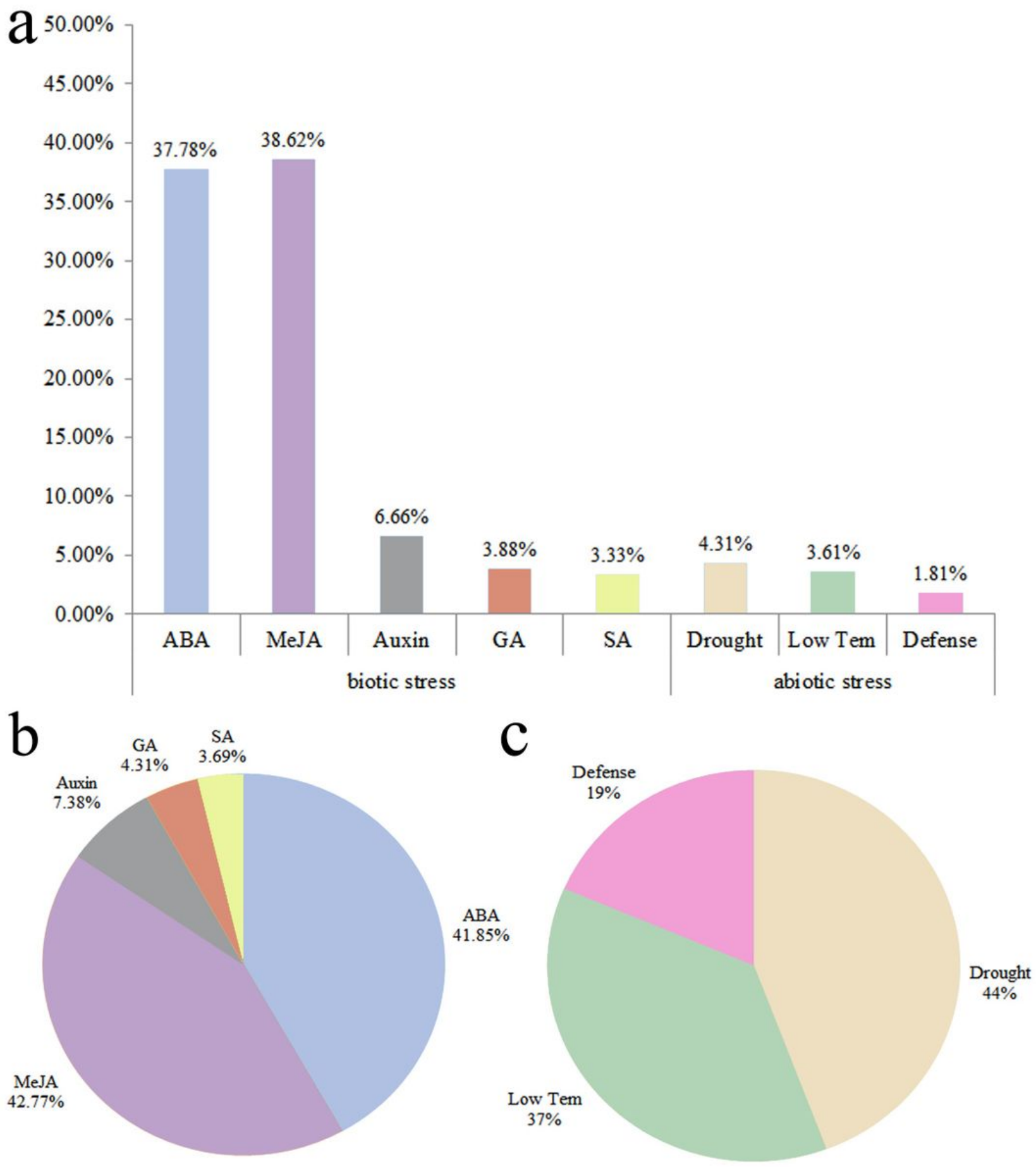

Figure 4

(caption not provided) 


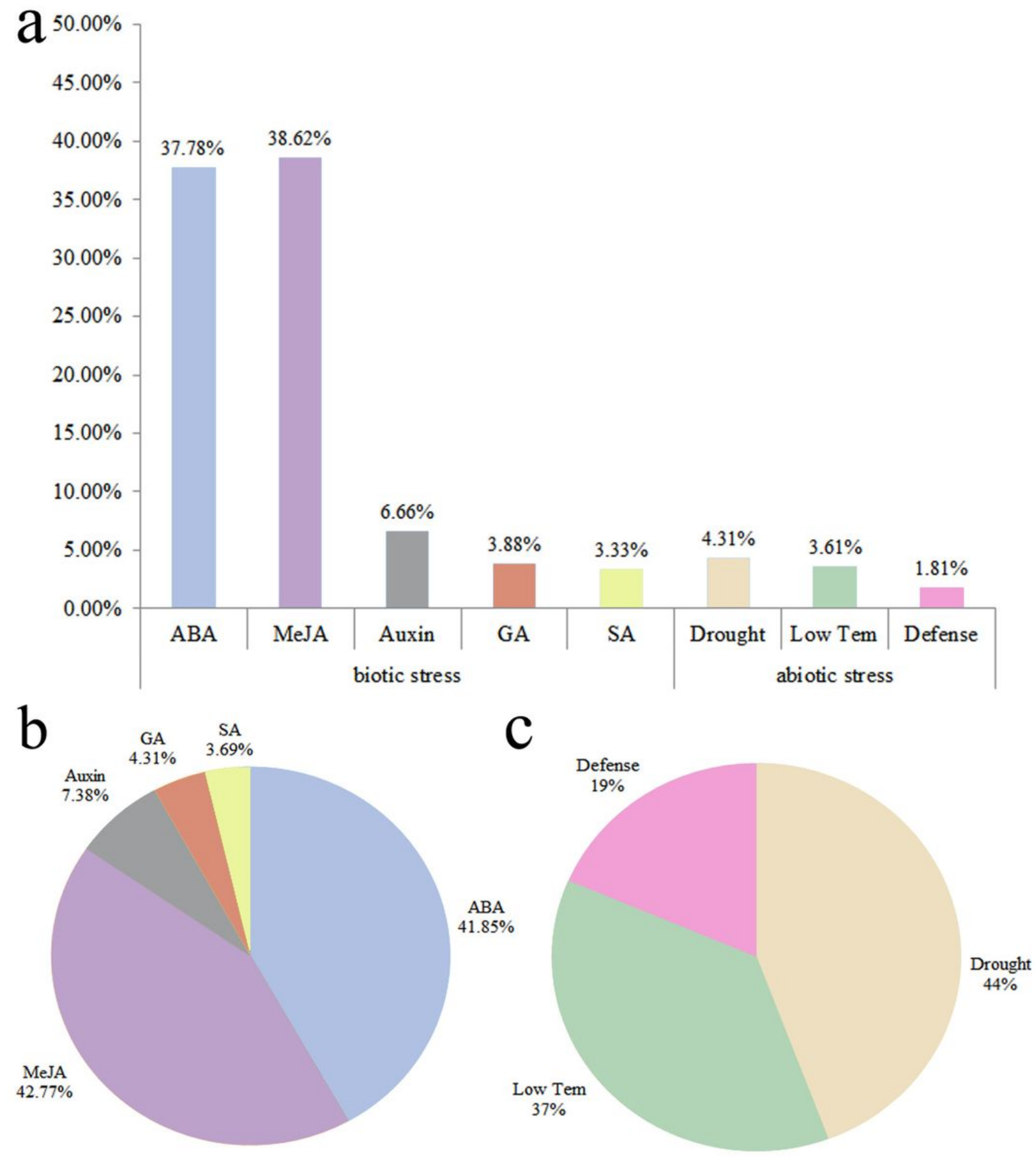

Figure 5

(caption not provided) 


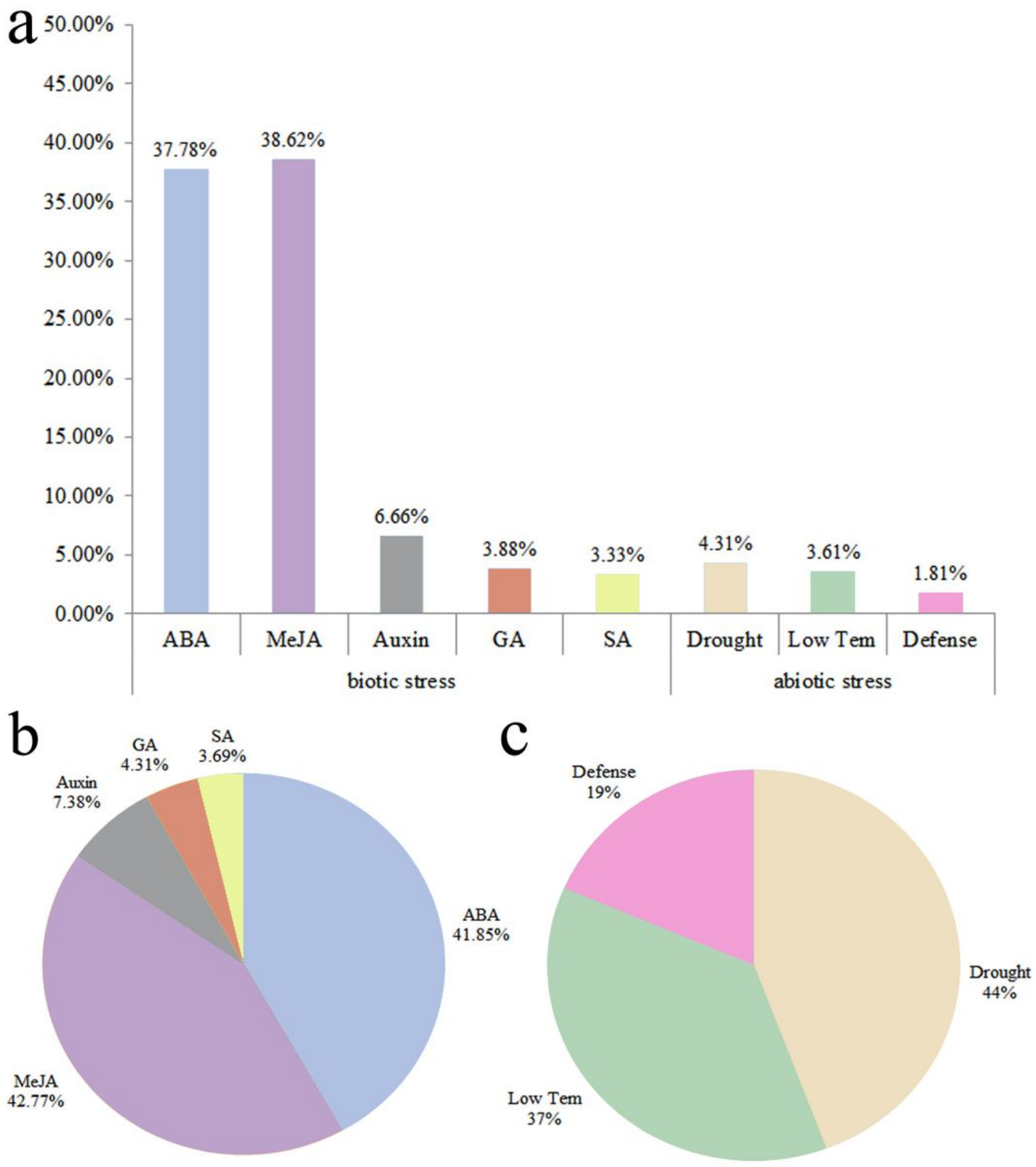

Figure 5

(caption not provided) 


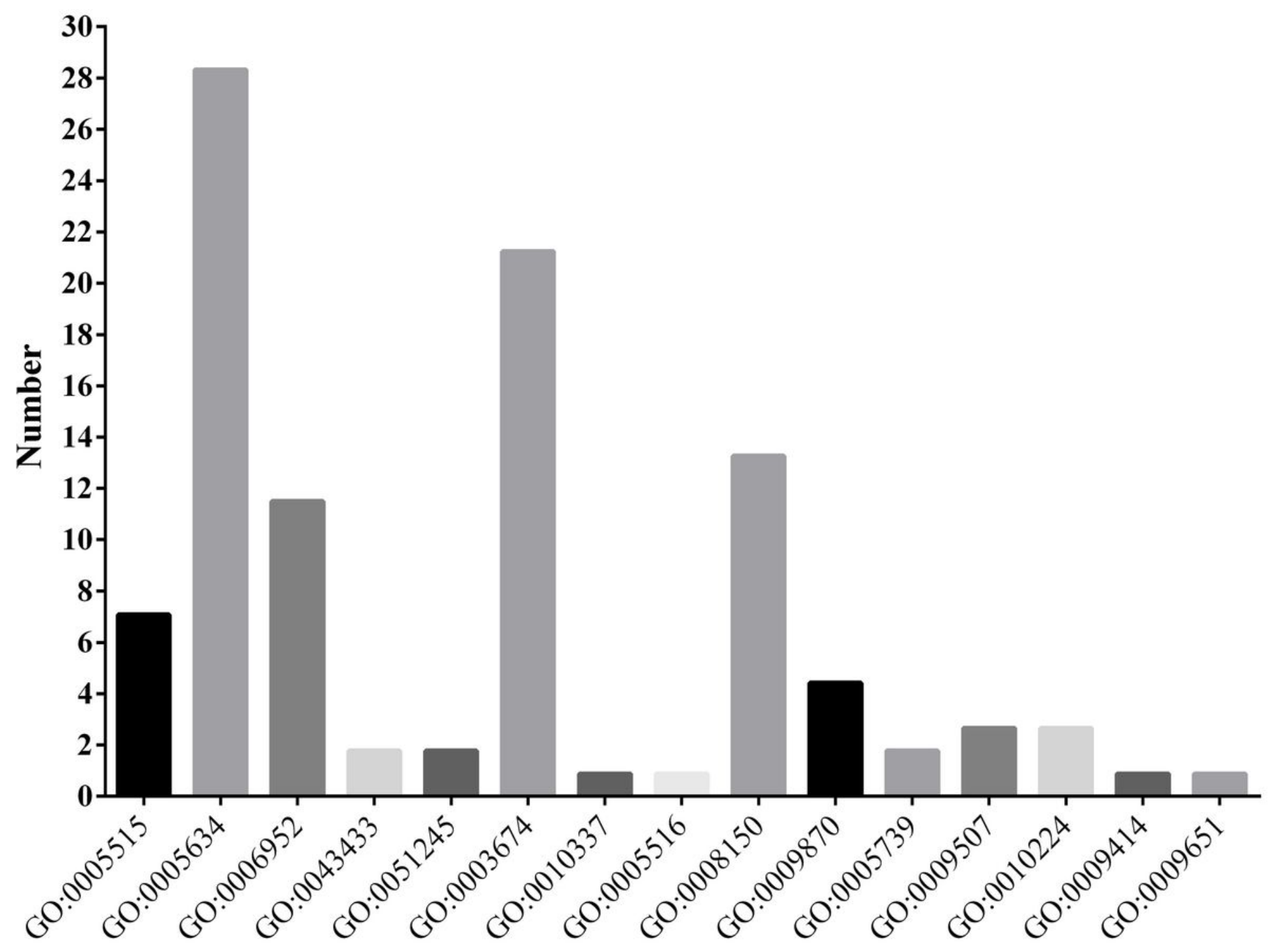

Figure 6

(caption not provided) 


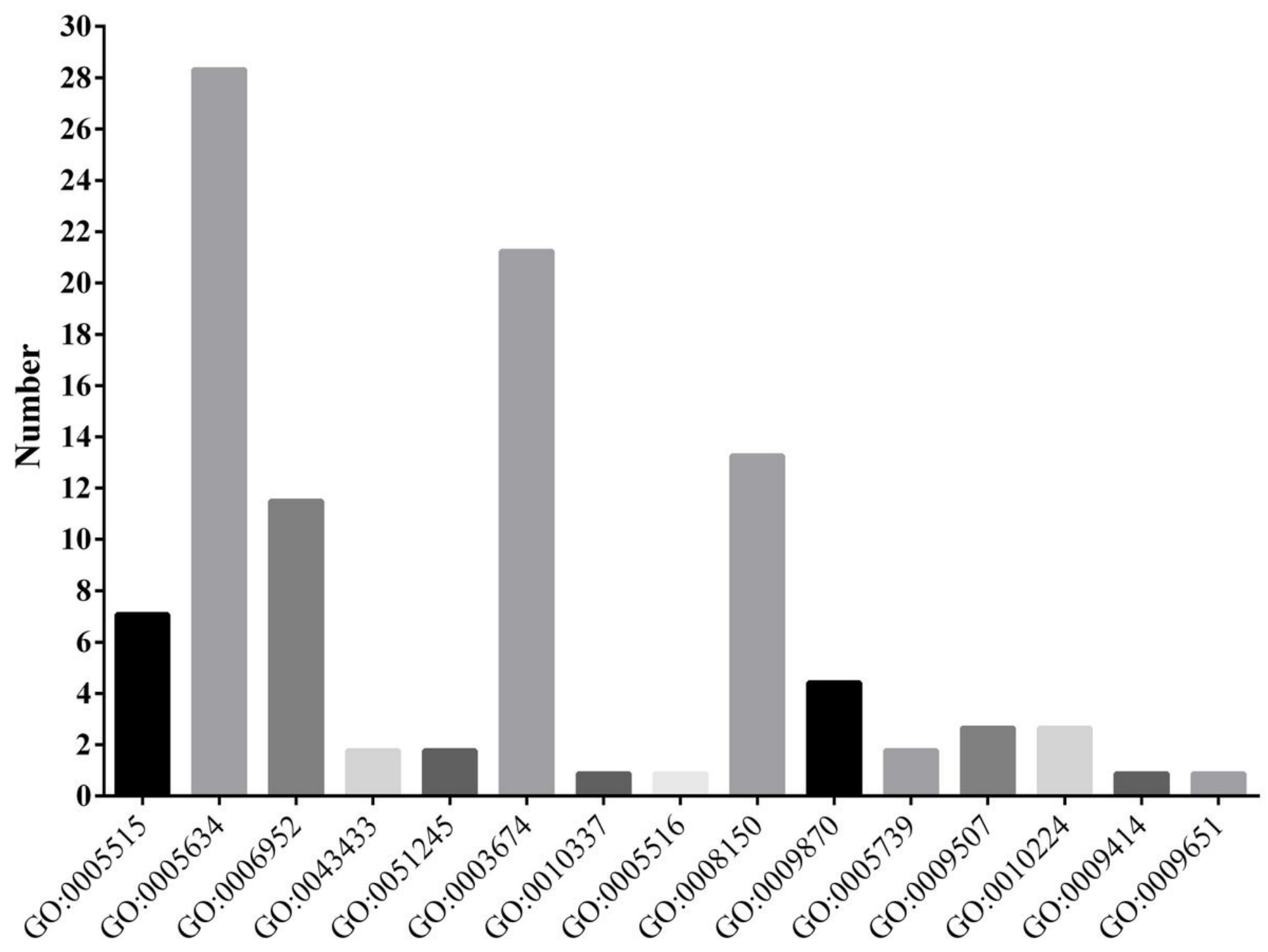

Figure 6

(caption not provided) 


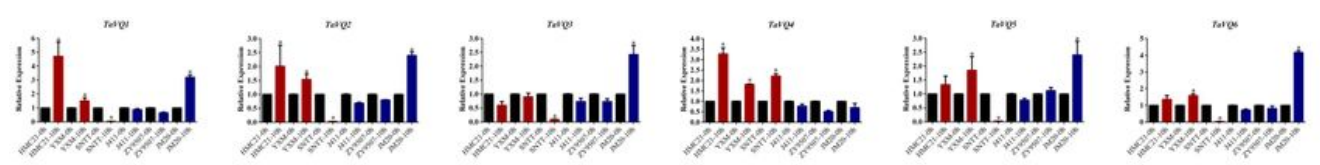

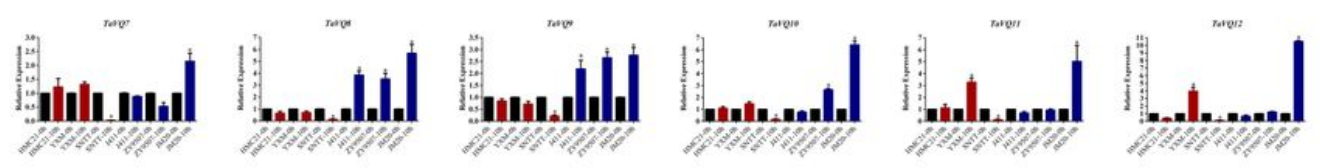

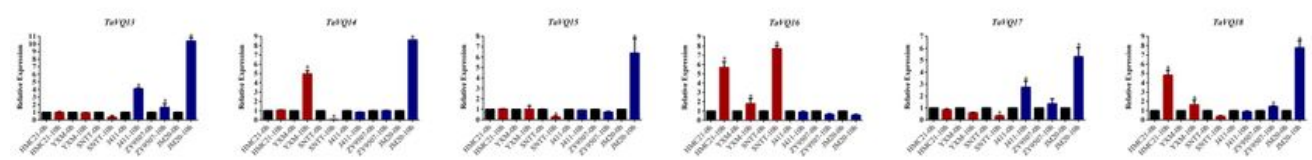

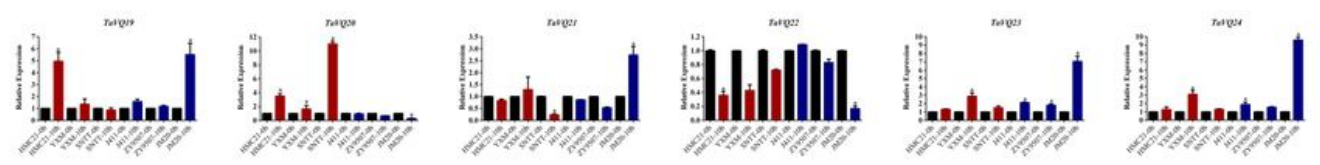

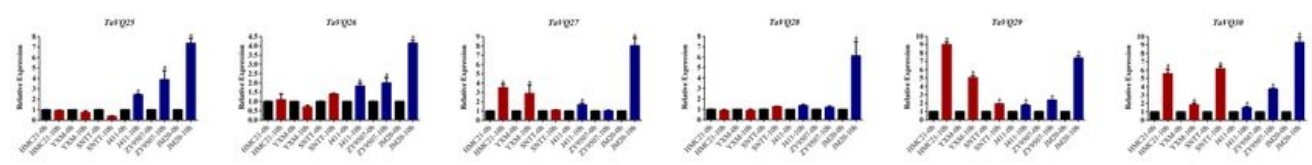

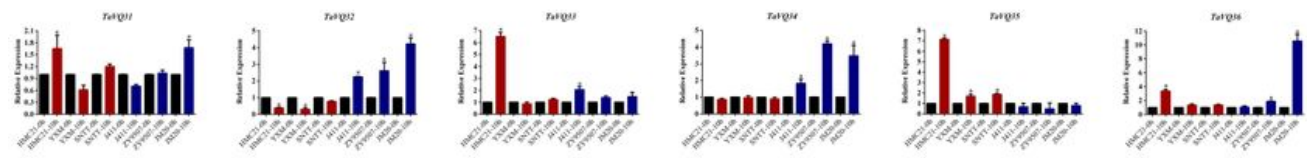

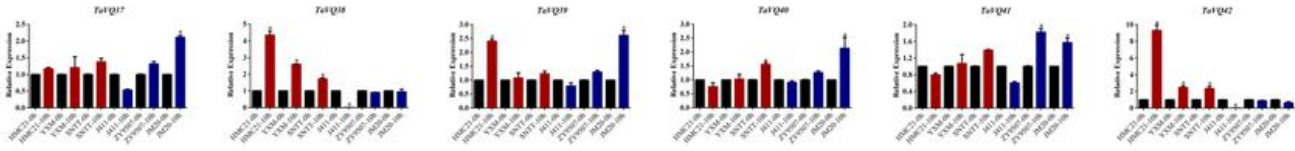

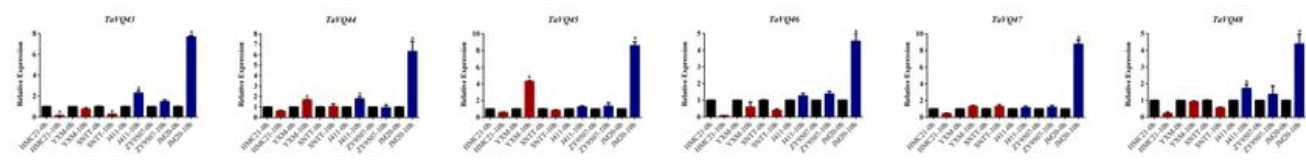

1:

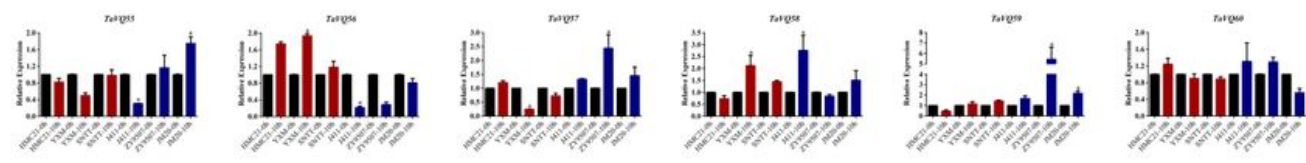

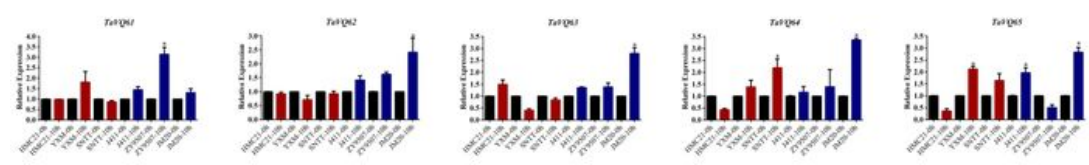

Figure 7

(caption not provided) 


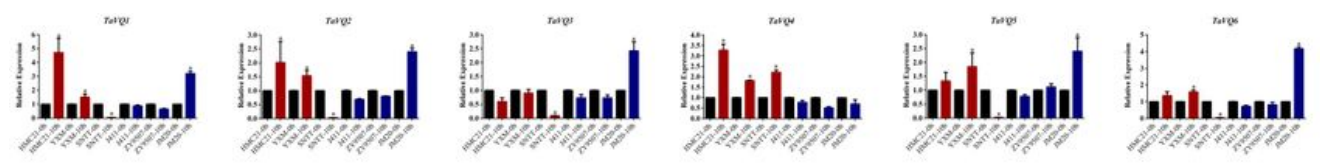

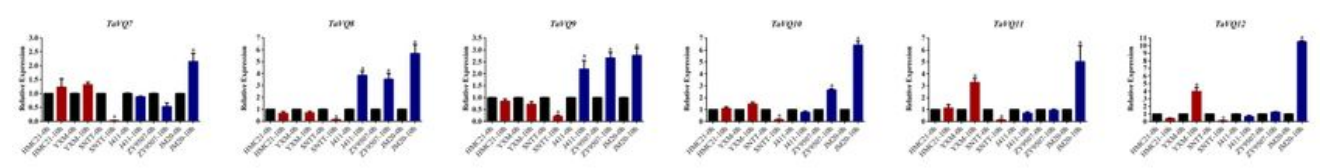
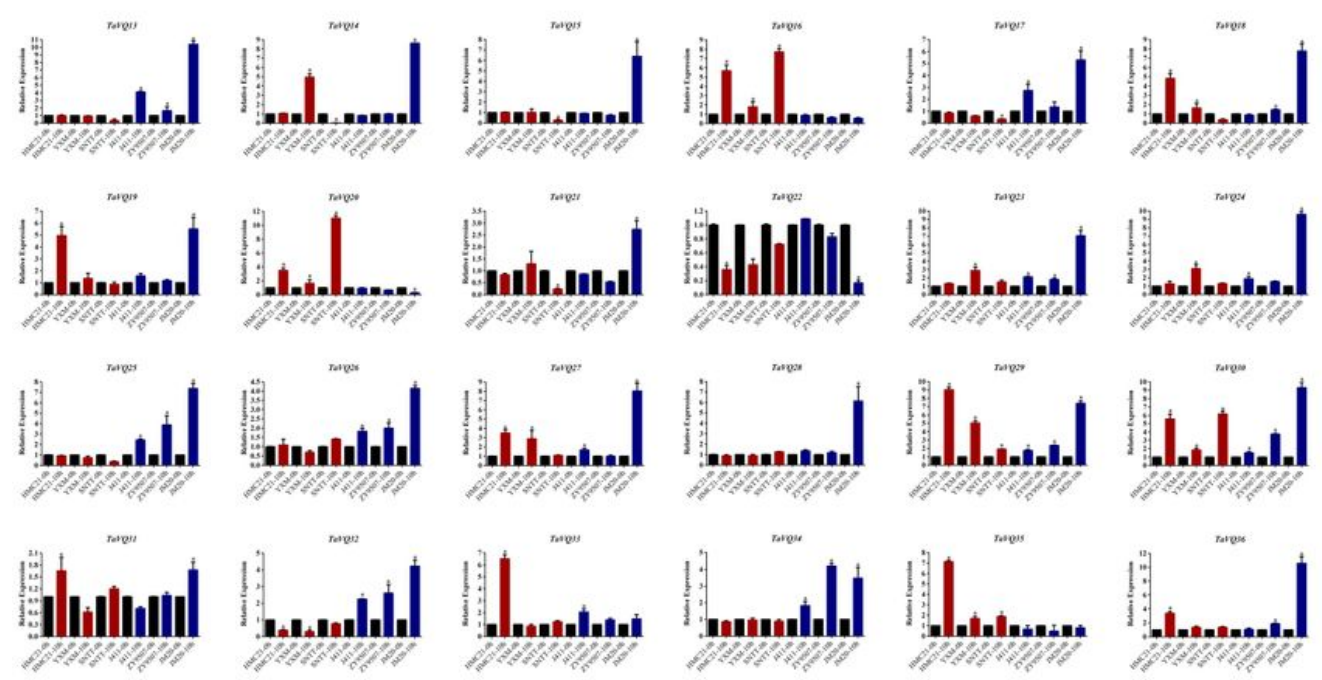

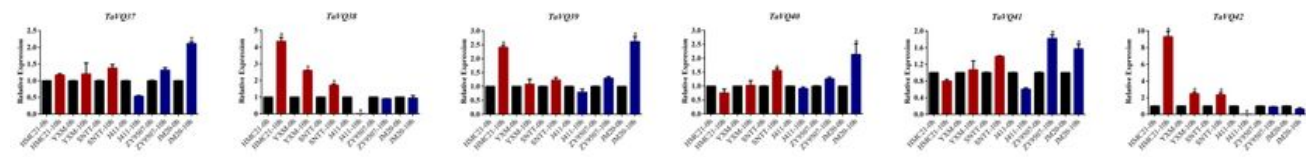
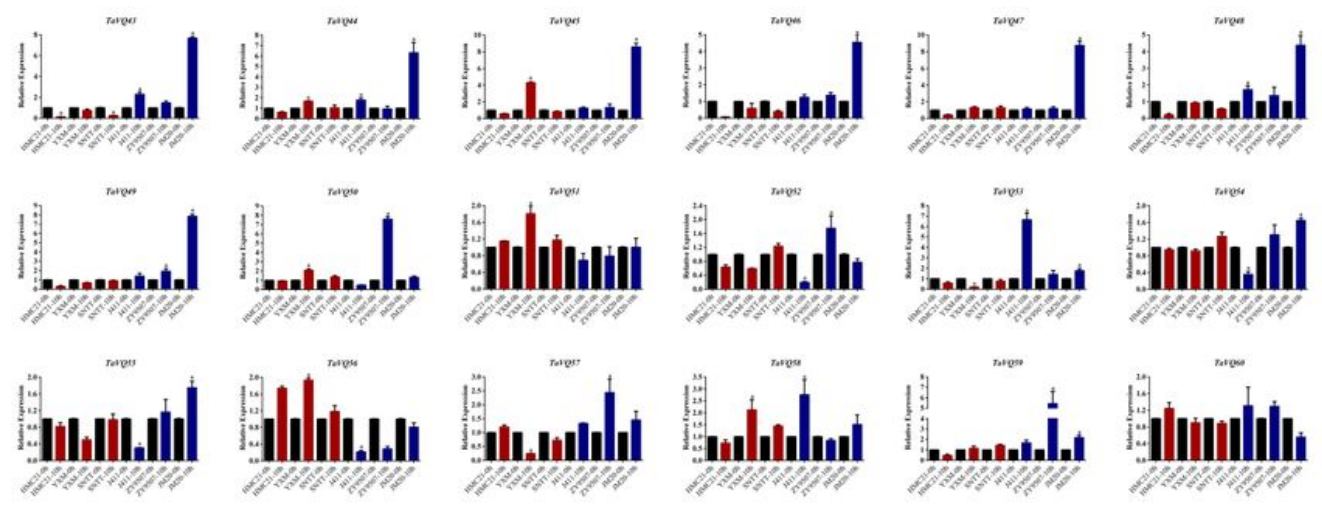

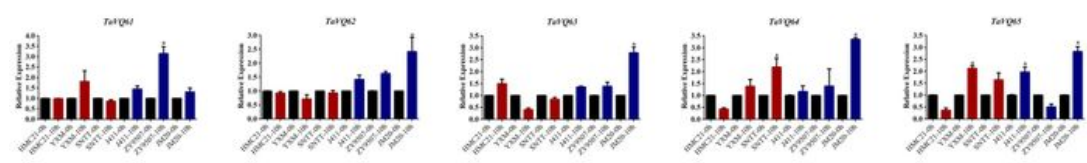

Figure 7

(caption not provided)

\section{Supplementary Files}

This is a list of supplementary files associated with this preprint. Click to download.

- Suppl.Material.docx

- Suppl.Material.docx 
- FigureS1.jpg

- FigureS1.jpg

- FigureS2.jpg

- FigureS2.jpg 